\title{
Anti-osteoporotic effects of mixed compositions of extracellular polymers isolated from Aureobasidium pullulans and Textoria morbifera in ovariectomized mice
}

Chang-Soo Cho ${ }^{1}$, Hye-Seong Jeong ${ }^{1}$, In-Young Kim¹', Go-Woon Jung ${ }^{2}$, Bon-Hwa Ku², Dong-Chan Park²,

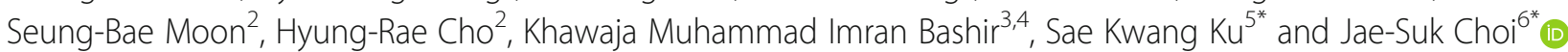

\begin{abstract}
Background: Extracellular polymeric substances isolated from Aureobasidium pullulans (EAP), containing specifically 13\% $\beta-1,3 / 1,6-$-glucan, have shown various favorable bone-preserving effects. Textoria morbifera Nakai (TM) tree has been used as an ingredient in traditional medicine and tea for various pharmacological purposes. Thus, the present study was aimed to examine the synergistic anti-osteoporotic potential of mixtures containing different proportions of EAP and TM compared with that of the single formulations of each herbal extract using bilateral ovariectomized (OVX) mice, a renowned rodent model for studying human osteoporosis.
\end{abstract}

Methods: Thirty five days after bilateral-OVX surgery, 9 combinations of EAP:TM (ratios=1:1, 1:3, 1:5, 1:7, 1:9, 3:1, 5:1, 7:1, 9:1) and single separate formulations of EAP or TM were supplied orally, once a day for 35 days at a final concentration of $200 \mathrm{mg} / \mathrm{kg}$. Variations in body weight gains during the experimental periods, as well as femur weights, bone mineral density (BMD), bone strength (failure load), and mineral content (calcium [Ca] and inorganic phosphorus [IP]) following sacrifice were measured. Furthermore, histomorphometric and histological profile analyses of serum biochemical parameters (osteocalcin content and bone specific alkaline phosphatase [bALP] activity) were conducted following sacrifice. Femurs histomorphometric analyses were also conducted for bone resorption, structure and mass. The results for the mixed formulations of EAP:TM and separate formulations were compared with those of risedronate sodium (RES).

Results: The EAP:TM (3:1) formulation synergistically enhanced the anti-osteoporotic potential of individual EAP or TM formulations, possibly due to enhanced variety of the active ingredients. Furthermore, the effects of EAP:TM were comparable to those of RES $(2.5 \mathrm{mg} / \mathrm{kg})$ treatment.

Conclusion: The results of this study suggest that, the EAP:TM (3:1) combination might act as a new pharmaceutical agent and/or health functional food substance for curing osteoporosis in menopausal women.

Keywords: Anti-osteoporotic effect, Aureobasidium pullulans, $\beta$-Glucans, Exopolymer, Textoria morbifera

\footnotetext{
*Correspondence: gucci200@hanmail.net; jsc1008@silla.ac.kr

${ }^{5}$ Department of Anatomy and Histology, College of Korean Medicine, Daegu

Haany University, 1, Hanuidae-ro, Gyeongsan-si, Gyeongsangbuk-do 38610,

Republic of Korea

${ }^{6}$ Major in Food Biotechnology, Division of Bioindustry, College of Medical

and Life Sciences, Silla University, 140, Baegyang-daero

700beon-gilSasang-gu, Busan 46958, Republic of Korea

Full list of author information is available at the end of the article
}

(c) The Author(s). 2018 Open Access This article is distributed under the terms of the Creative Commons Attribution 4.0 International License (http://creativecommons.org/licenses/by/4.0/), which permits unrestricted use, distribution, and reproduction in any medium, provided you give appropriate credit to the original author(s) and the source, provide a link to the Creative Commons license, and indicate if changes were made. The Creative Commons Public Domain Dedication waiver (http://creativecommons.org/publicdomain/zero/1.0/) applies to the data made available in this article, unless otherwise stated. 


\section{Background}

Osteoporosis is becoming an increasingly critical public health problem owing to the aging population. Although it is partially preventable, fractures related to osteoporosis are still common [1]. Osteoporosis, a metabolic bone disorder, causes an imbalance between the bone [2]. Thus, osteoporosis constitutes a major public health issue due to its association with age-related fractures, particularly of the hip, vertebrae, distal forearm, and humerus $[3,4]$. During the past decade, numerous studies have been reported on the effects of new substances for the prevention and/or treatment of bone disorders $[5,6]$. However, there is a need to develop an efficient resorptive inhibitor with higher safety. On-going trials to develop anabolic agents are typically designed through understanding bone formation and the differences in osteoblast [7-9].

Osteoclast-mediated bone resorption is inhibited by binding of risedronate sodium (RES) to bone hydroxyapatites [10]. RES, a pridinyl bisphosphonate, inhibits bone resorption by changing osteoclast cytoskeleton protein [11], and induces osteoclast apoptosis [12]. RES has been previously used for the curing osteoporosis in menopausal women [13]. Topical treatments with RES (at a concentration of $0.02 \%$ and $2.5 \mathrm{mg} / \mathrm{kg} /$ day) in OVX rat and/or mice have shown sustained bone biomechanical and microstructural features $[14,15]$. Hence, after OVX, oral administration of risedronate sodium $(2.5 \mathrm{mg} / \mathrm{kg}$ per day) was employed as a positive-control.

Textoria morbifera (TM) Nakai mainly grows in Jeju-do Island and along the Korean southwestern coastline $[16,17]$. It has been used as an ingredient for traditional medicine and tea for immunological enhancement [16-18]. Previously, TM extracts have exhibited numerous immunological activities, including anti-diabetic [19], antioxidant [20], anti-cancer [21], anti-insecticidal [22], anti-complementary effects, as well as antibiotic and medicinal effects for liver diseases [23]. Recently, TM extracts have been reported for anti-osteoclastogenic and osteoporosis ameliorating effects [24-26]. $\beta$-selinene, a sesquiterpene derivative and capnellane-8-one have been reported as the most abundant active ingredients of TM [27].

Polysaccharides are linked with host defense mechanisms [28]. The immunopharmacological effects of exopolymers, $\beta-1,3 / 1,6$-glucans, have been reported by in vitro, in vivo and clinical studies as well [29]. The key immunological features include anti-tumor activity [30], radioprotective actions [31], increased host resistance to microbial infections [32], as well as adjuvant effects [33]. In addition, exopolysaccharides isolated from Aureobasidium pullulans (EAP) contain $13 \% \beta-1,3 / 1,6$-glucan $[34,35]$ as a major ingredient. The exopolymers isolated from A. pullulans have demonstrated favorable anti-osteoporotic [8, 35], fracture healing [36], anti-inflammatory [37, 38], and potent immunomodulatory activities in mouse models [39]. These extracts have also shown favorable nephroprotective effects [40], ameliorative activity against ovalbumin-induced asthma [41], and anti-osteoarthritic effects [42, 43].

It has been reported that the various pharmacological effects of natural products are synergistically increased by appropriate mixed formulations [9, 44-46]. Specifically, the bone-preserving characteristics of EAP have been potentiated by combining it with other active agents [47-49]. Therefore, it was hypothesized that the mixed formulations of exopolymer (EAP) and leaf extracts of TM (EAP:TM) might show favorable synergistic anti-osteoporotic properties due to enhanced availability of the bioactive substances.

In this study, we aimed to investigate the optimal compositions of EAP:TM mixtures that are associated with clear synergistic anti-osteoporotic potential compared with the single formulations, using bilateral OVX female mice, a renowned rodent model for studying human osteoporosis [7, 9].

\section{Methods}

\section{Animal husbandry}

One hundred and sixty virgin female SPF/VAF (CrljOri:CD1 [ICR]; 7-weeks old) mice, purchased from OrientBio, Seungnam, Republic of Korea, were acclimatized for 8 days and then used for these experiments. Four mice were assigned per polycarbonate cage and reared in a humidity $(45-55 \%)$, and temperature $\left(20-25^{\circ} \mathrm{C}\right)$, -controlled room. Light was provided for $12 \mathrm{~h}$ and the standard rodent chow diet (Purinafeed, Seungnam, Rep. of Korea) and water were provided freely. In this experiment, 150 mice were allocated as OVX-operated osteoporosis model and 10 mice were allocated as sham-operated control. After 34 days of OVX operation, 8 mice from each group were chosen depending on body weight deviations (OVX-mice: $37.38 \pm 2.71 \mathrm{~g}$, range of $34.2 \sim 44.4 \mathrm{~g}$; sham-operated mice: $33.86 \pm 2.53 \mathrm{~g}$, range of 30.3 $37.5 \mathrm{~g})$. The experimental designs for this study are presented in Fig. 1, and the animals were assigned to the experimental groups as follows:

1. Sham vehicle control: Sham-operated and distilled water administered

2. OVX control: OVX and distilled water administered

3. RES: OVX and treated with RES $(2.5 \mathrm{mg} / \mathrm{kg})$

4. EAP: OVX and treated with $200 \mathrm{mg} / \mathrm{kg}$ of EAP single formulation

5. TM: OVX and treated with $200 \mathrm{mg} / \mathrm{kg}$ of TM single formulation

6. OVX mice treated with 9 different EAP:TM mixed formulations

6-1.EAP:TM 1:1 (g/g) $200 \mathrm{mg} / \mathrm{kg}(100: 100 \mathrm{mg} / \mathrm{kg})$ 


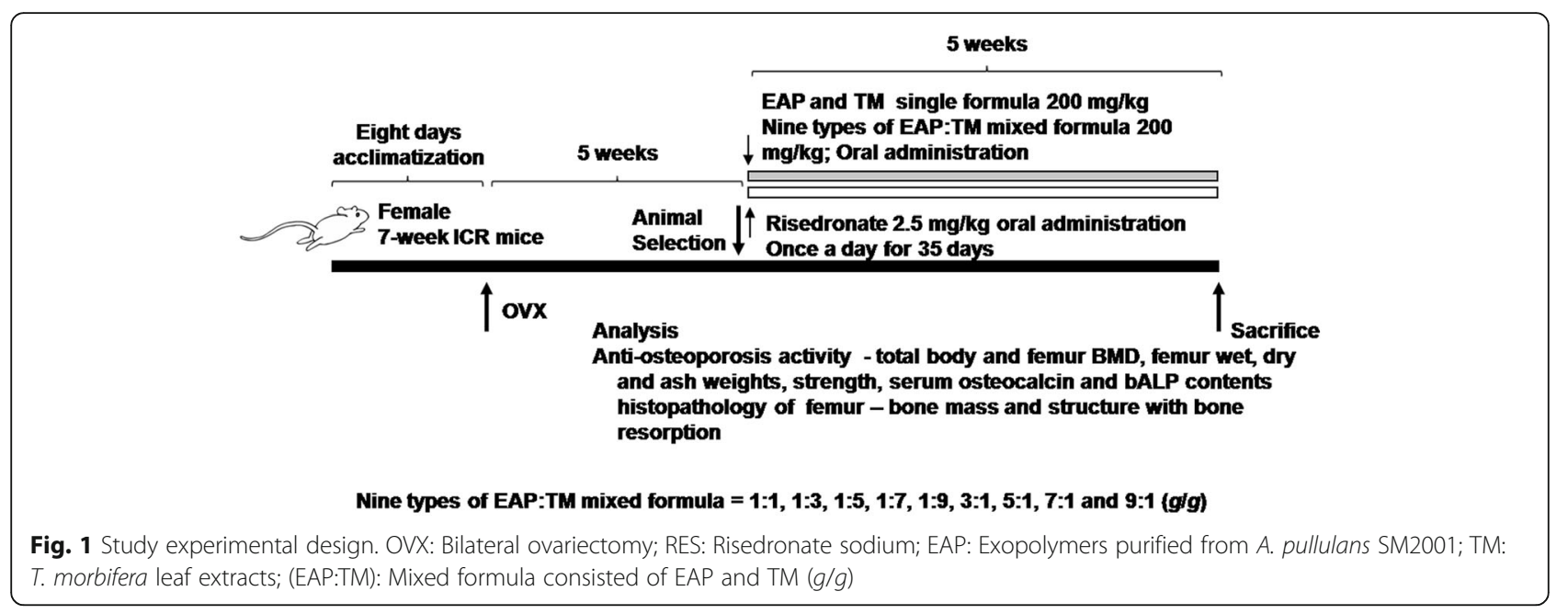

6-2.EAP:TM 1:3 (g/g) $200 \mathrm{mg} / \mathrm{kg}(50: 150 \mathrm{mg} / \mathrm{kg})$ 6-3.EAP:TM 1:5 (g/g) $200 \mathrm{mg} / \mathrm{kg}(33: 167 \mathrm{mg} / \mathrm{kg})$ 6-4.EAP:TM 1:7 (g/g) $200 \mathrm{mg} / \mathrm{kg}(25: 175 \mathrm{mg} / \mathrm{kg})$ 6-5.EAP:TM 1:9 (g/g) $200 \mathrm{mg} / \mathrm{kg}(20: 180 \mathrm{mg} / \mathrm{kg})$ 6-6.EAP:TM 3:1 (g/g) $200 \mathrm{mg} / \mathrm{kg}(150: 50 \mathrm{mg} / \mathrm{kg})$ 6-7.EAP:TM 5:1 (g/g) $200 \mathrm{mg} / \mathrm{kg}(167: 33 \mathrm{mg} / \mathrm{kg})$ 6-8.EAP:TM 7:1 (g/g) $200 \mathrm{mg} / \mathrm{kg}(175: 25 \mathrm{mg} / \mathrm{kg})$ 6-9.EAP:TM 9:1 (g/g) $200 \mathrm{mg} / \mathrm{kg}(180: 20 \mathrm{mg} / \mathrm{kg})$

\section{Preparation and administration of test materials}

EAP, an extracellular polymer isolated from $A$. pullulans (SM-2001; marketed as Polycan $\left.{ }^{\mathrm{Tm}}\right)$ and the standard leaf extract of T. morbifera (TM) were obtained from Glucan Corp., Busan, Rep. of Korea. EAP consisted of $40 \%$ total $\beta$-glucans including $13 \% \beta$-1,3/1,6-glucans [34, 35]. EAP and TM were mixed thoroughly in distilled water to a final concentration of $20 \mathrm{mg} / \mathrm{ml}$. A few samples of TM [Code No: TM2016Ku01], and EAP [Code No: EAP2016Ku01] were deposited in the herbarium, Medical Research Center for Globalization of Herbal Formulation, Daegu Haany University, Gyeongsangbuk-do, Gyeongsan-si, Rep. of Korea. The 9 different herbal formulations at a final concentration of $200 \mathrm{mg} / \mathrm{kg} /$ body weight (EAP:TM = 1:1, 1:3, 1:5, 1:7, 1:9, 3:1, 5:1, 7:1, and 9:1) and both single formulations of TM and EAP were supplied orally, once a day for 35 days after 35 days of OVX surgery. The EAP:TM mixed formulations (1:1, 1:3, 1:5, 1:7, 1:9, 3:1, 5:1, 7:1, and 9:1) were prepared by dissolving EAP and TM (100:100, 50:150, 33:167, $25: 175, \quad 20: 180, \quad 150: 50, \quad 167: 33, \quad 175: 25, \quad$ and 180:20 mg:mg) in distilled water, respectively (final concentration: $200 \mathrm{mg}$ in $10 \mathrm{ml}$ of distilled water). The prepared mixtures were then provided at a concentration of $200 \mathrm{mg} / \mathrm{kg}$, by gastric gavages using a $1 \mathrm{ml}$ syringe. The single formulations of EAP and
TM were also prepared and administrated in the same manner as other mixed formulations of EAP and TM.

In addition, $0.25 \mathrm{mg}$ risedronate sodium (RES; TEVA Tapi, Sheva, Israel) was also dissolved in $1 \mathrm{ml}$ distilled water and provided orally at a concentration of $2.5 \mathrm{mg} / \mathrm{kg}[10,15]$. The control groups (OVX and Sham control) were provided with equal volumes of distilled water (vehicle) instead of test substance to provide the same experimental conditions and administration stress.

\section{Osteoporosis induction}

A mixture of 2 to $3 \%$ isoflurane $[2-3 \%$ isoflurane in 28.5\% $\mathrm{O}_{2}$ and $70 \% \mathrm{~N}_{2} \mathrm{O}$ ], was used to anesthetize the animals using a rodent inhalation and rodent ventilator system and the animals were maintained with 1 to $1.5 \%$ isoflurane. The surgical protocol was carried out according to the previously reported methods [7-9]. In the OVX treatment group, bilateral OVX was removed by open surgery and the incisions were stitched in two steps. The bilateral OVX surgery was not performed in the sham operated mice group (2nd group). The animals were sacrificed by cervical dislocation under anesthesia using 99.50\% $\mathrm{CO}_{2}$ gas and the stomach was excised with a median incision in the abdomen.

\section{Body weight measurements}

The changes in body weights were recorded on weekly basis by an automatic electronic balance. At the initiation and termination of sample administration as well as on the day of OVX, all trial mice were starved for approximately $18 \mathrm{~h}$ (only water was supplied) to decrease alterations due to feeding. Furthermore, body weight gains were estimated by Eq. [1], and Eq. [2]. 


$$
\begin{aligned}
& \text { Body weight gains after administration (35 days) } \\
& =\text { Body weight at sacrifice } \\
& \quad-\text { Body weight at initial provision of test material }
\end{aligned}
$$

Body weight gains during OVX recovery/induced periods (35 days)

$=$ Body weight at initial provision of test material

-body weight at OVX surgery

\section{Estimation of BMD}

In vivo dual-energy X-ray absorptiometry was used to estimate the changes in mean BMD of the right femur and the total body, $24 \mathrm{~h}$ after the final administration of the test materials.

\section{Measurement of bone weight}

After 35 days continuous treatment with the test material, right side of the femur was collected and the bone absolute wet-weights were recorded after weighting the bones; however, dry-weights were measured after drying the bones at $200{ }^{\circ} \mathrm{C}$ for $8 \mathrm{~h}$. In addition, the bone absolute ash weights were measured after carbonizing the dried bones in a furnace at $800{ }^{\circ} \mathrm{C}$ for $6 \mathrm{~h}$ [8]. The individual body weight variances were minimized by calculating the relative weights (\% body weights) using the Eq. [3].

$$
\begin{aligned}
& \text { Relative bone weights }=(3) \\
& \begin{array}{c}
{[(\text { Absolute bone weight/Body weight at sacrifice })} \\
\times 100]
\end{array}
\end{aligned}
$$

\section{Estimation of bone strength}

Bone strengths [Failure load (FL); unit: Newton (N)] of the mid-shaft regions of femurs (dried right femur) were measured through a three-point bending failure stress test by a computerized testing machine as reported previously $[8,50]$.

\section{Serum biochemical analysis}

At sacrifice, whole blood (approximately $1 \mathrm{ml}$ ) was collected in a serum collection tube and the serum was separated by centrifugation at $15,000 \mathrm{rpm}$ for $10 \mathrm{~min}$ under $4{ }^{\circ} \mathrm{C}$. All collected samples were stored at $-150{ }^{\circ} \mathrm{C}$ using an Ultra-deep freezer (Sanyo, Tokyo, Japan) until further analysis. Mouse Osteocalcin ELIZA Kit and Mouse bALP ELIZA Kit, purchased from MyBioSource (CA, USA), were used for measuring the serum osteocalcin and bALP levels, respectively.

\section{Femur mineral contents}

The ground bone ash powder was dissolved in nitric acid $\left(\mathrm{HNO}_{3}\right)$ and the inorganic phosphate (IP) and calcium $(\mathrm{Ca})$ contents were measured by the previously reported $o$-cresolphthalein complexone [7], and enzyme [8] methods, respectively. Furthermore, Ca/IP ratios were determined by Eq. [4].

$$
\text { Bone } \mathrm{Ca} / \mathrm{IP} \text { ratio }=[(\text { Bone Ca content } / \text { Bone IP content })] \times 100
$$

\section{Histopathological analyses of bone}

The separated left femur of each mouse was fixed in 10\% neutral buffered formalin and decalcified for 3 days in a decalcifying solution [24.4\% formic acid and $0.5 \mathrm{~N}$ sodium hydroxide]. Following decalcification, femur trochlea head regions were longitudinally trimmed, embedded in paraffin, sectioned in 3-4 $\mu \mathrm{m}$, and stained with hematoxylin and eosin (HE). In each prepared histological sample, the histological profiles were interpreted. The prepared histological samples were coded for blind histopathological analysis. Bone histomorphometry was performed by an automated image analyzer and the bone structure, resorption, and mass were measured in the cortical or epiphyseal regions of the femur. Thickness of the cortical bone was measured in the femurs' mid-shaft region. Trabecular bone thickness (Tbt), length (Tbl), number (Tbn) and volume (TBV), and thickness of cortical bone (Cbt) for structure and mass, and osteoclast cell number (Ocn) and osteoclast cell ratios (OS/BS) were estimated for bone resorption [7-9].

\section{Statistical analysis}

The experimental data is stated as mean \pm standard deviation (S.D.) of eight animals. Different doses of test material were compared by the multiple comparison tests. Levene's test was used to examine the variance homogeneity [51]. If no significant deviation was observed by the Levene's test, then the obtained data was evaluated by one-way ANOVA by least-significant differences multi-comparison (LSD) test. If a significant deviation from variance was observed by the Levene's test, groups were compared by a non-parametric comparison test (Kruskal-Wallis $\mathrm{H}$ test). If the Kruskal-Wallis $\mathrm{H}$ test showed a significant difference, the Mann-Whitney $U$ test was performed to estimate the significantly different specific pairs of groups. Differences were considered significant at $p<0.05$ and/or $p<0.01$. SPSS ver. 14 (IBM-SPSS Inc., Chicago, IL, USA) was used for the statistical analyses [52]. To estimate the effectiveness of the test material, the percent fluctuations between treated-mice and the OVX-control were estimated respectively by Eq. [5], and Eq. [6] as demonstrated previously [53]. 
Percent differences compared with OVX control (\%) $=[($ data for test material treated mice - data for OVX control)/data for OVX control\} $\times 100$ ]

Percent differences compared with the sham control (\%)

$$
\begin{aligned}
= & {[\text { data for OVX control mice }} \\
- \text { data for sham control mice }) & \\
& / \text { data for sham control mice }\} \times 100]
\end{aligned}
$$

\section{Results}

\section{Changes in body weight and weight gain}

Eight mice from each group showing significant $(p<0.05)$ increases in body weights were selected for OVX models 34-days post-surgery [OVX mice: $37.38 \pm 2.71 \mathrm{~g}$, weight range of $34.2 \mathrm{~g}$ to $44.4 \mathrm{~g}$; sham-operated mice: $33.86 \pm$ $2.53 \mathrm{~g}$, weight range $30.3 \mathrm{~g}$ to $37.5 \mathrm{~g}$ ]. All OVX-control groups revealed significant increases in body weights.
Furthermore, significantly $(p<0.01 ; p<0.05)$ higher body weight gains were observed in OVX-mice during the 5-weeks of OVX recovery/induction period. Although, obvious decreases in body weights were noticed during some periods of treatment with EAP:TM 1:1, 1:5, 3:1, and 7:1 as compared with the OVX-mice; animals treated with all EAP and TM formulations showed significant $(p<0.01)$ decreases in body weight gains. Specifically, EAP:TM (3:1) treated OVX mice revealed significant $(p<0.05)$ reductions in body weight gains as compared with mice treated with other formulations. RES $(2.5 \mathrm{mg} / \mathrm{kg})$-treated mice showed no significant variations in body weights and body weight gains throughout the entire experimental period (Table 1; Additional file 1).

\section{Effects on femur weight}

OVX control groups showed significant decreases in absolute and relative wet, dry, and ash weights of femur as compared with that in sham control groups. Conversely, noticeable increases in wet, dry, and ash weights of femur were demonstrated by all mice administered with

\begin{tabular}{|c|c|c|c|c|c|c|}
\hline \multirow{2}{*}{$\begin{array}{l}\text { Periods } \\
\text { Groups }\end{array}$} & \multicolumn{4}{|c|}{ Body weights (g) } & \multicolumn{2}{|c|}{ Body weight gains (g) } \\
\hline & $\begin{array}{l}\text { At OVX } \\
{[A]^{*}}\end{array}$ & At 34 days after OVX [B] & At initial treatment $[C]^{*}$ & $\begin{array}{l}\text { At sacrifice } \\
{[\mathrm{D}]^{*}}\end{array}$ & $\begin{array}{l}\text { OVX recovery } \\
{[B-A]}\end{array}$ & $\begin{array}{l}\text { Treatment } \\
{[\mathrm{D}-\mathrm{C}]}\end{array}$ \\
\hline \multicolumn{7}{|l|}{ Controls } \\
\hline Sham & $25.55 \pm 1.62$ & $33.86 \pm 2.53$ & $29.90 \pm 2.56$ & $31.45 \pm 2.74$ & $8.31 \pm 1.88$ & $1.46 \pm 0.92$ \\
\hline OVX & $25.51 \pm 1.20$ & $37.40 \pm 3.22^{b}$ & $33.96 \pm 2.84^{a}$ & $37.59 \pm 2.75^{a}$ & $11.89 \pm 2.90^{\mathrm{a}}$ & $3.63 \pm 0.73^{a}$ \\
\hline \multicolumn{7}{|c|}{ Reference $(2.5$ mg/kg) } \\
\hline RES & $26.29 \pm 0.80$ & $36.68 \pm 1.71^{b}$ & $33.40 \pm 1.68^{b}$ & $35.75 \pm 2.80^{a}$ & $10.39 \pm 1.53^{b}$ & $2.35 \pm 2.11$ \\
\hline \multicolumn{7}{|c|}{ Single formula (200 mg/kg) } \\
\hline EAP & $26.61 \pm 1.59$ & $37.70 \pm 3.22^{a}$ & $34.00 \pm 2.62^{a}$ & $35.08 \pm 1.90^{a}$ & $11.09 \pm 3.11^{b}$ & $1.08 \pm 1.76^{\mathrm{c}}$ \\
\hline $\mathrm{TM}$ & $25.99 \pm 1.35$ & $37.31 \pm 3.20^{b}$ & $34.10 \pm 2.99^{a}$ & $35.06 \pm 2.57^{a}$ & $11.33 \pm 2.55^{a}$ & $0.96 \pm 0.78^{c}$ \\
\hline \multicolumn{7}{|c|}{ Mixed formula - EAP:TM (200 mg/kg) } \\
\hline $1: 1$ & $25.60 \pm 1.82$ & $36.59 \pm 1.87$ & $33.18 \pm 1.83^{b}$ & $34.53 \pm 2.11^{b d}$ & $10.99 \pm 2.10^{a}$ & $1.35 \pm 1.47^{c}$ \\
\hline $1: 3$ & $26.80 \pm 2.21$ & $37.63 \pm 3.03^{a}$ & $34.26 \pm 2.74^{a}$ & $35.24 \pm 3.58^{a}$ & $10.83 \pm 2.29^{b}$ & $0.98 \pm 1.41^{c}$ \\
\hline $1: 5$ & $25.60 \pm 1.01$ & $37.58 \pm 2.92^{b}$ & $33.80 \pm 2.63^{a}$ & $34.69 \pm 3.91^{b d}$ & $11.98 \pm 3.34^{\mathrm{a}}$ & $0.89 \pm 2.03^{c}$ \\
\hline $1: 7$ & $26.73 \pm 1.88$ & $37.49 \pm 2.95^{\mathrm{b}}$ & $33.84 \pm 2.53^{\mathrm{a}}$ & $34.91 \pm 2.49^{b}$ & $10.79 \pm 2.27^{b}$ & $1.08 \pm 2.23^{c}$ \\
\hline $1: 9$ & $26.39 \pm 1.14$ & $37.55 \pm 2.98^{b}$ & $34.08 \pm 2.67^{a}$ & $35.23 \pm 1.75^{a}$ & $11.16 \pm 2.53^{\mathrm{a}}$ & $1.15 \pm 1.73^{c}$ \\
\hline $3: 1$ & $25.93 \pm 1.27$ & $37.51 \pm 2.99^{b}$ & $33.79 \pm 2.76^{a}$ & $32.76 \pm 2.66^{c}$ & $11.59 \pm 2.83^{a}$ & $-1.03 \pm 1.43^{\text {acef }}$ \\
\hline $5: 1$ & $26.13 \pm 1.24$ & $37.54 \pm 2.87^{b}$ & $34.00 \pm 2.75^{a}$ & $34.99 \pm 2.52^{b}$ & $11.41 \pm 3.27^{a}$ & $0.99 \pm 1.92^{c}$ \\
\hline $7: 1$ & $26.11 \pm 0.96$ & $37.48 \pm 2.89^{b}$ & $33.96 \pm 2.69^{a}$ & $34.91 \pm 3.10^{b}$ & $11.36 \pm 2.62^{a}$ & $0.95 \pm 1.25^{\mathrm{c}}$ \\
\hline $9: 1$ & $26.44 \pm 1.66$ & $37.50 \pm 2.80^{b}$ & $34.05 \pm 2.79^{a}$ & $35.05 \pm 2.15^{a}$ & $11.06 \pm 2.50^{a}$ & $1.00 \pm 1.71^{c}$ \\
\hline
\end{tabular}
test substances, including RES as compared with OVX

Table 1 Body weight gain in sham-operated and OVX mice

OVX Bilateral ovariectomy, RES Risedronate sodium, EAP Exopolymers purified from A. pullulans SM2001, TM T. morbifera leaf extracts, (EAP:TM) Mixed formula consisted of EAP and TM $(g / g)$

Values are expressed mean \pm S.D. of eight mice

*All animals were overnight fasted

${ }^{\mathrm{a}} p<0.01$ and ${ }^{\mathrm{b}} p<0.05$ as compared with sham control by LSD test

${ }^{c} p<0.01$ and ${ }^{d} p<0.05$ as compared with OVX control by LSD test

${ }^{\mathrm{e}} p<0.05$ as compared with EAP single formula treated mice by LSD test

${ }^{f} p<0.05$ as compared with TM single formula treated mice by LSD test 
controls. In particular, EAP:TM 3:1-treated groups exhibited significantly $(p<0.01 ; p<0.05)$ higher femur relative wet-weights, and absolute and relative dry and ash weights as compared with the mice administered with EAP or TM single formulations (Table 2; Additional file 2).

\section{Effects on serum biochemical parameters: Osteocalcin content and bALP activities}

OVX control groups displayed a significant $(p<0.01)$ decline in serum bALP activity and a noteworthy rise in serum osteocalcin. However, all formulations of EAP and TM significantly $(p<0.01)$ reduced the serum osteocalcin levels and significantly $(p<0.01)$ increased the bALP activity. Particularly, EAP:TM (3:1) treated mice revealed significant $(p<0.01 ; p<0.05)$ decreases in serum osteocalcin content and increases in serum bALP activity. RES $(2.5 \mathrm{mg} / \mathrm{kg})$ supplied OVX mice also showed significantly $(p<0.01)$ decreases in serum osteocalcin levels; yet, both groups demonstrated similar serum bALP activity compared to the OVX control group (Figs. 2 and 3; Additional file 3).

\section{Effects on femur BMD}

A significantly decreased total body and femur mean BMD were observed in OVX mice. However, the test substances-administered groups showed significantly increased femur mean BMD and total body, including the EAP single formulation, compared with that in OVX control mice. In particular, EAP:TM (3:1)-treated mice showed significant $(p<0.01)$ increased femur mean BMD and total body as compared to mice supplied with the single formulations of EAP or TM (Table 3; Fig. 4; Additional file 4).

\section{Effects on bone strength}

The strength (FL) of the mid-shaft region of the right dry femur in OVX mice showed noteworthy decreases; while, significant $(p<0.01 ; p<0.05)$ increases in the femur FL were detected in all groups treated with test substances, including TM single formulations, compared with that in OVX controls. Specifically, EAP:TM (3:1)-treated mice consistently showed significant $(p<0.01)$ increases in the femur FL compared to mice treated with single formulations of EAP or TM (Table 3; Additional file 5).

\section{Changes in femur mineral contents}

OVX mice showed significant $(p<0.01)$ decreases in femur $\mathrm{Ca}$ and IP contents. While, a significantly $(p<0.01$; $p<0.05)$ increased trend in femur Ca and IP contents was observed in all groups treated with the test substances,

Table 2 Right femur weights of sham-operated and OVX mice

\begin{tabular}{|c|c|c|c|c|c|c|}
\hline \multirow{2}{*}{$\begin{array}{l}\text { Items } \\
\text { Groups }\end{array}$} & \multicolumn{3}{|c|}{ Absolute weight (g) } & \multicolumn{3}{|c|}{ Relative weight (\% of body weight) } \\
\hline & Wet & Dry & Ash & Wet & Dry & Ash \\
\hline \multicolumn{7}{|l|}{ Controls } \\
\hline Sham & $0.094 \pm 0.006$ & $0.067 \pm 0.004$ & $0.049 \pm 0.003$ & $0.300 \pm 0.030$ & $0.214 \pm 0.016$ & $0.157 \pm 0.012$ \\
\hline ovx & $0.091 \pm 0.006$ & $0.047 \pm 0.003^{\mathrm{a}}$ & $0.027 \pm 0.002^{\mathrm{a}}$ & $0.243 \pm 0.017^{a}$ & $0.126 \pm 0.012^{a}$ & $0.071 \pm 0.007^{\mathrm{a}}$ \\
\hline RES $2.5 \mathrm{mg} / \mathrm{kg}$ & $0.098 \pm 0.007$ & $0.066 \pm 0.004^{c}$ & $0.046 \pm 0.003^{b c}$ & $0.274 \pm 0.022^{b c}$ & $0.185 \pm 0.019^{a c}$ & $0.128 \pm 0.012^{\mathrm{ac}}$ \\
\hline EAP 200 mg/kg & $0.093 \pm 0.006$ & $0.058 \pm 0.005^{\mathrm{ac}}$ & $0.034 \pm 0.003^{\mathrm{ac}}$ & $0.266 \pm 0.008^{\mathrm{ad}}$ & $0.164 \pm 0.007^{\mathrm{ac}}$ & $0.097 \pm 0.005^{\mathrm{ac}}$ \\
\hline TM 200 mg/kg & $0.094 \pm 0.007$ & $0.058 \pm 0.005^{\mathrm{ac}}$ & $0.035 \pm 0.003^{\mathrm{ac}}$ & $0.269 \pm 0.026^{b d}$ & $0.166 \pm 0.013^{\mathrm{ac}}$ & $0.100 \pm 0.008^{\mathrm{ac}}$ \\
\hline \multicolumn{7}{|c|}{ Mixed formula - EAP:TM (200 mg/kg) } \\
\hline $1: 1$ & $0.094 \pm 0.007$ & $0.056 \pm 0.005^{\mathrm{ac}}$ & $0.035 \pm 0.003^{\mathrm{ac}}$ & $0.272 \pm 0.029^{b d}$ & $0.163 \pm 0.019^{a c}$ & $0.102 \pm 0.011^{\mathrm{ac}}$ \\
\hline $1: 3$ & $0.095 \pm 0.009$ & $0.058 \pm 0.005^{\mathrm{ac}}$ & $0.035 \pm 0.004^{\mathrm{ac}}$ & $0.270 \pm 0.024^{\mathrm{bd}}$ & $0.165 \pm 0.015^{\mathrm{ac}}$ & $0.100 \pm 0.012^{\mathrm{ac}}$ \\
\hline $1: 5$ & $0.093 \pm 0.007$ & $0.057 \pm 0.004^{\mathrm{ac}}$ & $0.034 \pm 0.003^{\mathrm{ac}}$ & $0.270 \pm 0.026^{b d}$ & $0.166 \pm 0.025^{a c}$ & $0.100 \pm 0.014^{\mathrm{ac}}$ \\
\hline $1: 7$ & $0.094 \pm 0.004$ & $0.056 \pm 0.002^{\mathrm{ac}}$ & $0.034 \pm 0.001^{\mathrm{ac}}$ & $0.272 \pm 0.027^{\mathrm{bd}}$ & $0.162 \pm 0.015^{\mathrm{ac}}$ & $0.098 \pm 0.009^{\mathrm{ac}}$ \\
\hline $1: 9$ & $0.096 \pm 0.008$ & $0.058 \pm 0.005^{\mathrm{ac}}$ & $0.035 \pm 0.002^{\mathrm{ac}}$ & $0.272 \pm 0.025^{\mathrm{bd}}$ & $0.165 \pm 0.018^{a c}$ & $0.100 \pm 0.009^{\mathrm{ac}}$ \\
\hline $3: 1$ & $0.098 \pm 0.009$ & $0.065 \pm 0.003^{\text {cef }}$ & $0.044 \pm 0.004^{\text {cef }}$ & $0.300 \pm 0.027^{\mathrm{ceg}}$ & $0.200 \pm 0.017^{\text {cef }}$ & $0.134 \pm 0.011^{\text {acef }}$ \\
\hline $5: 1$ & $0.095 \pm 0.008$ & $0.056 \pm 0.005^{\mathrm{ac}}$ & $0.036 \pm 0.004^{a c}$ & $0.272 \pm 0.021^{\mathrm{bd}}$ & $0.169 \pm 0.014^{\mathrm{ac}}$ & $0.103 \pm 0.016^{\mathrm{ac}}$ \\
\hline $7: 1$ & $0.094 \pm 0.009$ & $0.058 \pm 0.005^{\mathrm{ac}}$ & $0.035 \pm 0.003^{\mathrm{ac}}$ & $0.268 \pm 0.017^{\mathrm{ad}}$ & $0.166 \pm 0.010^{\mathrm{ac}}$ & $0.100 \pm 0.006^{\mathrm{ac}}$ \\
\hline $9: 1$ & $0.095 \pm 0.005$ & $0.060 \pm 0.005^{a c}$ & $0.035 \pm 0.003^{\mathrm{ac}}$ & $0.271 \pm 0.022^{b d}$ & $0.171 \pm 0.012^{\mathrm{ac}}$ & $0.100 \pm 0.007^{\mathrm{ac}}$ \\
\hline
\end{tabular}

OVX Bilateral ovariectomy, RES Risedronate sodium, EAP Exopolymers purified from A. pullulans SM2001, TM T. morbifera leaf extracts, (EAP:TM) Mixed formula consisted of EAP and TM $(g / g)$

Values are expressed mean \pm S.D. of eight mice

${ }^{\mathrm{a}} p<0.01$ and ${ }^{\mathrm{b}} p<0.05$ as compared with sham control by LSD test

$\mathrm{e}_{p}<0.01$ as compared with EAP single formula treated mice by LSD test

${ }^{c} p<0.01$ and ${ }^{d} p<0.05$ as compared with OVX control by LSD test

${ }^{f} p<0.01$ and ${ }^{9} p<0.05$ as compared with TM single formula treated mice by LSD test 


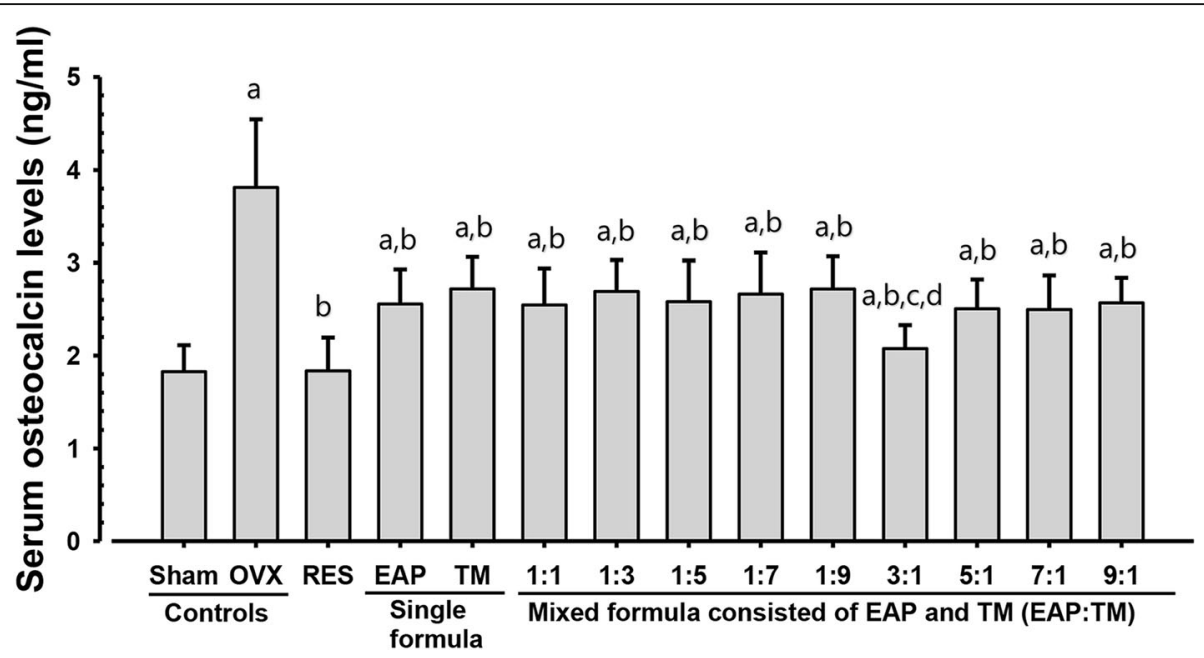

Fig. 2 Serum osteocalcin levels in sham-operated and OVX mice. OVX: Bilateral ovariectomy; RES: Risedronate sodium; EAP: Exopolymers purified from A. pullulans SM2001; TM: T. morbifera leaf extracts; (EAP:TM): Mixed formula consisted of EAP and TM (g/g). Values are expressed mean \pm S.D. of eight mice. RES was orally administered at a dose level of $2.5 \mathrm{mg} / \mathrm{kg}$. All single and mixed formula consisted of EAP and TM were administered at a dose level of totalized $200 \mathrm{mg} / \mathrm{kg}$ by gastric gavage. ${ }^{\mathrm{a}} p<0.01$ as compared with sham control by LSD test. ${ }^{b} p<0.01$ as compared with OVX control by LSD test. ${ }^{c} p<0.05$ as compared with EAP single formula treated mice by LSD test. ${ }^{d} p<0.01$ as compared with TM single formula treated mice by LSD test

especially in mice treated with EAP:TM (3:1). No noteworthy variation in femur $\mathrm{Ca} / \mathrm{IP}$ ratio was observed in OVX mice compared with that in sham control. Furthermore, no significant differences in femur $\mathrm{Ca} / \mathrm{IP}$ ratios were detected in mice administered with the test substances, including RES $(2.5 \mathrm{mg} / \mathrm{kg})$, compared with that in the OVX control group (Table 3; Additional file 6).

\section{Changes in femur histopathology}

OVX control mice showed a typical osteoporotic histological profile, whereas left femur of the sham-control mice showed relatively well-developed cortical and trabecular bones. The periosteum of cortical bones showed increased connective tissues, however, a dramatic decrease in cortical and trabecular bone mass was observed. Although, RES reduced the trabecular bone loss,

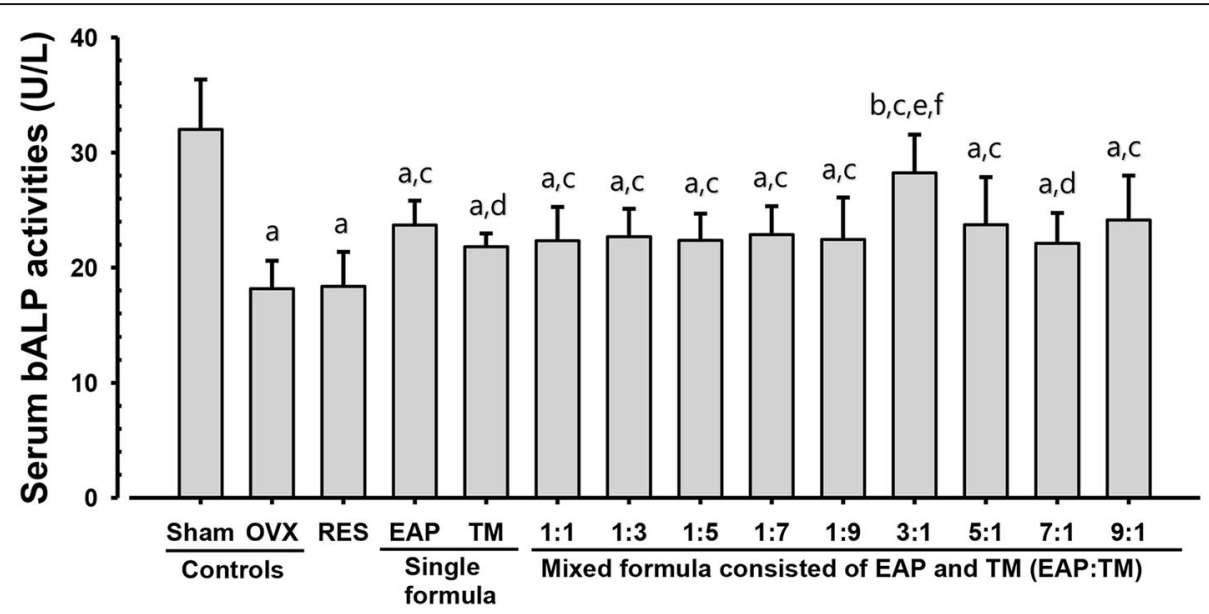

Fig. 3 Serum bALP levels in sham-operated and OVX mice. OVX: Bilateral ovariectomy; RES: Risedronate sodium; EAP: Exopolymers purified from A. pullulans SM2001; TM: T. morbifera leaf extracts; (EAP:TM): Mixed formula consisted of EAP and TM $(\mathrm{g} / \mathrm{g})$. Values are expressed mean \pm S.D. of eight mice. OVX = Bilateral ovariectomy; RES = Risedronate sodium; RES was orally administered at a dose level of $2.5 \mathrm{mg} / \mathrm{kg}$. All single and mixed formula consisted of EAP and TM were administered at a dose level of totalized $200 \mathrm{mg} / \mathrm{kg}$ by gastric gavage. ${ }^{\mathrm{a}} p<0.01$ and ${ }^{\mathrm{b}} p<0.05$ as compared with sham control by LSD test. ${ }^{c} p<0.01$ and ${ }^{d} p<0.05$ as compared with OVX control by LSD test. ${ }^{p} p<0.01$ as compared with EAP single formula treated mice by LSD test. ${ }^{f} p<0.01$ as compared with TM single formula treated mice by LSD test 
Table 3 Bone femur strength, and mineral content (Ca and IP) in sham-operated and OVX mice

\begin{tabular}{|c|c|c|c|c|c|c|}
\hline \multirow{2}{*}{$\begin{array}{l}\text { Items } \\
\text { Groups }\end{array}$} & \multicolumn{2}{|c|}{ Bone Mineral Density $\left(\mathrm{g} / \mathrm{cm}^{2}\right)$} & \multirow{2}{*}{$\begin{array}{l}\text { Strength (Newton) } \\
\text { Right femur }\end{array}$} & \multicolumn{3}{|c|}{ Right femur bone mineral contents } \\
\hline & Total body & Right femur & & Ca (mg/g bone) & IP (mg/g bone) & $\mathrm{Ca} / \mathrm{IP}$ ratio \\
\hline \multicolumn{7}{|l|}{ Controls } \\
\hline Sham & $0.0249 \pm 0.0007$ & $0.0274 \pm 0.0008$ & $12.47 \pm 1.66$ & $59.08 \pm 10.25$ & $45.42 \pm 7.57$ & $1.30 \pm 0.07$ \\
\hline ovx & $0.0215 \pm 0.0003^{f}$ & $0.0231 \pm 0.0001^{\mathrm{a}}$ & $6.69 \pm 0.91^{f}$ & $33.37 \pm 3.32^{f}$ & $26.14 \pm 3.26^{f}$ & $1.28 \pm 0.11$ \\
\hline RES $2.5 \mathrm{mg} / \mathrm{kg}$ & $0.0251 \pm 0.0008^{h}$ & $0.0262 \pm 0.0013^{b c}$ & $11.27 \pm 1.78^{h}$ & $55.33 \pm 11.04^{h}$ & $44.03 \pm 10.17^{\mathrm{h}}$ & $1.26 \pm 0.05$ \\
\hline EAP 200 mg/kg & $0.0233 \pm 0.0003^{\mathrm{fh}}$ & $0.0252 \pm 0.0007^{\mathrm{ac}}$ & $8.59 \pm 0.63^{\text {th }}$ & $42.76 \pm 4.14^{\text {fh }}$ & $33.27 \pm 3.18^{\text {fh }}$ & $1.29 \pm 0.06$ \\
\hline TM 200 mg/kg & $0.0231 \pm 0.0004^{\text {fh }}$ & $0.0248 \pm 0.0006^{\mathrm{ac}}$ & $7.96 \pm 0.69^{f i}$ & $39.28 \pm 3.84^{f i}$ & $31.32 \pm 3.51^{\text {th }}$ & $1.26 \pm 0.06$ \\
\hline \multicolumn{7}{|c|}{ Mixed formula - EAP:TM (200 mg/kg) } \\
\hline $1: 1$ & $0.0333 \pm 0.0003^{\mathrm{fh}}$ & $0.0253 \pm 0.0006^{\mathrm{ac}}$ & $8.32 \pm 0.98^{\text {th }}$ & $40.63 \pm 2.92^{\text {fh }}$ & $31.79 \pm 2.93^{\mathrm{fh}}$ & $1.28 \pm 0.07$ \\
\hline $1: 3$ & $0.0232 \pm 0.0003^{\mathrm{fh}}$ & $0.0253 \pm 0.0008^{\mathrm{ac}}$ & $8.04 \pm 0.67^{\mathrm{fi}}$ & $40.77 \pm 3.43^{\mathrm{fi}}$ & $32.39 \pm 3.40^{f i}$ & $1.26 \pm 0.06$ \\
\hline 1:5 & $0.0231 \pm 0.0003^{\text {fh }}$ & $0.0250 \pm 0.0010^{\mathrm{ac}}$ & $8.23 \pm 0.86^{\text {th }}$ & $41.48 \pm 4.10^{\text {fh }}$ & $32.85 \pm 3.64^{\text {fh }}$ & $1.27 \pm 0.09$ \\
\hline $1: 7$ & $0.0232 \pm 0.0004^{\mathrm{fh}}$ & $0.0252 \pm 0.0009^{\mathrm{ac}}$ & $8.08 \pm 0.88^{\text {th }}$ & $40.39 \pm 1.58^{\text {fh }}$ & $31.51 \pm 1.58^{\mathrm{fh}}$ & $1.28 \pm 0.04$ \\
\hline $1: 9$ & $0.0232 \pm 0.0003^{\text {fh }}$ & $0.0249 \pm 0.0008^{\mathrm{ac}}$ & $8.29 \pm 0.84^{\mathrm{fi}}$ & $40.35 \pm 4.00^{f i}$ & $32.17 \pm 3.02^{f i}$ & $1.25 \pm 0.05$ \\
\hline $3: 1$ & $0.0244 \pm 0.0005^{\mathrm{hjl}}$ & $0.0268 \pm 0.0011^{\text {cde }}$ & $10.58 \pm 1.17^{\mathrm{ghjl}}$ & $48.96 \pm 2.87^{\mathrm{hhjl}}$ & $38.25 \pm 2.96^{\mathrm{ghkl}}$ & $1.28 \pm 0.06$ \\
\hline $5: 1$ & $0.0234 \pm 0.0006^{\mathrm{fh}}$ & $0.0256 \pm 0.0015^{\mathrm{ac}}$ & $8.48 \pm 0.81^{\text {th }}$ & $42.67 \pm 5.16^{\text {th }}$ & $33.66 \pm 4.52^{\text {fh }}$ & $1.27 \pm 0.06$ \\
\hline $7: 1$ & $0.0232 \pm 0.0004^{\text {fh }}$ & $0.0249 \pm 0.0010^{\mathrm{ac}}$ & $8.36 \pm 0.54^{\text {th }}$ & $42.25 \pm 3.11^{\text {fh }}$ & $33.26 \pm 3.28^{\text {fh }}$ & $1.28 \pm 0.09$ \\
\hline 9:1 & $0.0232 \pm 0.0003^{\text {fh }}$ & $0.0250 \pm 0.0005^{\mathrm{ac}}$ & $8.45 \pm 0.69^{\text {th }}$ & $40.21 \pm 3.74^{\text {fh }}$ & $31.61 \pm 2.00^{\mathrm{fh}}$ & $1.27 \pm 0.05$ \\
\hline
\end{tabular}

OVX Bilateral ovariectomy, RES Risedronate sodium, EAP Exopolymers purified from A. pullulans SM2001, TM T. morbifera leaf extracts, (EAP:TM) Mixed formula consisted of EAP and TM $(g / g)$, Ca Calcium, IP Inorganic phosphorus Values are expressed mean \pm S.D. of eight mice

${ }^{\mathrm{a}} p<0.01$ and ${ }^{\mathrm{b}} p<0.05$ as compared with sham control by LSD test

${ }^{d} p<0.01$ as compared with EAP single formula treated mice by LSD test

${ }^{c} p<0.01$ as compared with OVX control by LSD test

${ }^{\mathrm{e}} p<0.01$ as compared with TM single formula treated mice by LSD test

${ }^{f} p<0.01$ and ${ }^{9} p<0.05$ as compared with sham control by MW test

${ }^{\mathrm{j}} p<0.01$ and ${ }^{\mathrm{k}} p<0.05$ as compared with EAP single formula treated mice by MW test

${ }^{h} p<0.01$ and $p<0.05$ as compared with OVX control by MW test

I $p<0.01$ as compared with TM single formula treated mice by MW test

no changes in cortical bone masses were observed. However, a dramatic increase in bone structure and mass of cortical and trabecular bones was observed for all the tested formulations; especially, EAP:TM (3:1) treated groups showed a visible inhibition in the bone mass loss of femur and the histopathological activation of osteoclast cells than the other treatment groups (Tables 4 and 5; Fig. 5).

\section{Bone structure and mass}

The OVX controls displayed significant $(p<0.01)$ decreases in femur Tbl, Tbn, Tbt, Cbt and TV/BV as compared to the sham-operated controls. However, all EAP:TM formulations including the single formulations significantly $(p<0.01 ; p<0.05)$ inhibited the decreases in bone structure and mass. In particular, EAP:TM (3:1)-treated mice showed significantly $(p<0.01)$ increased inhibition of bone mass depletion and destruction of structures induced by OVX. RES treated groups also displayed increases in TV/BV, Tbn, and Tbl of the left femur, but femur Cbt and Tbt showed no significant differences compared with that of OVX mice (Tables 4 and 5; Fig. 5; Additional file 7).

\section{Bone resorption}

OVX control mice displayed increased femur Ocn and OS/BS ratios as compared with the sham control mice. However, the stimulation and escalation of osteoclast cells was significantly $(p<0.01)$ repressed by treatment with all EAP:TM formulations including the single formulations; particularly, EAP:TM 3:1-treated groups consistently exhibited significant $(p<0.01)$ increases in the inhibition of osteoclast cell activation and proliferation. Although RES-treated mice exhibited comparable left femur Ocn as that of the OVX control mice, OS/BS ratios were significantly deceased as compared to that in the OVX controls (Table 5; Fig. 5; Additional file 8).

\section{Discussion}

Estrogen deficiency during menopause is one of the major causes of osteoporosis in menopausal women [54]. A disturbance in bone formation and resorption results in fractures and bone loss, ultimately causing osteoporosis [2]. Antiresorptive agents are well known compared to the bone formation stimulant anabolic agents [6]. In depth understanding of bone formation 


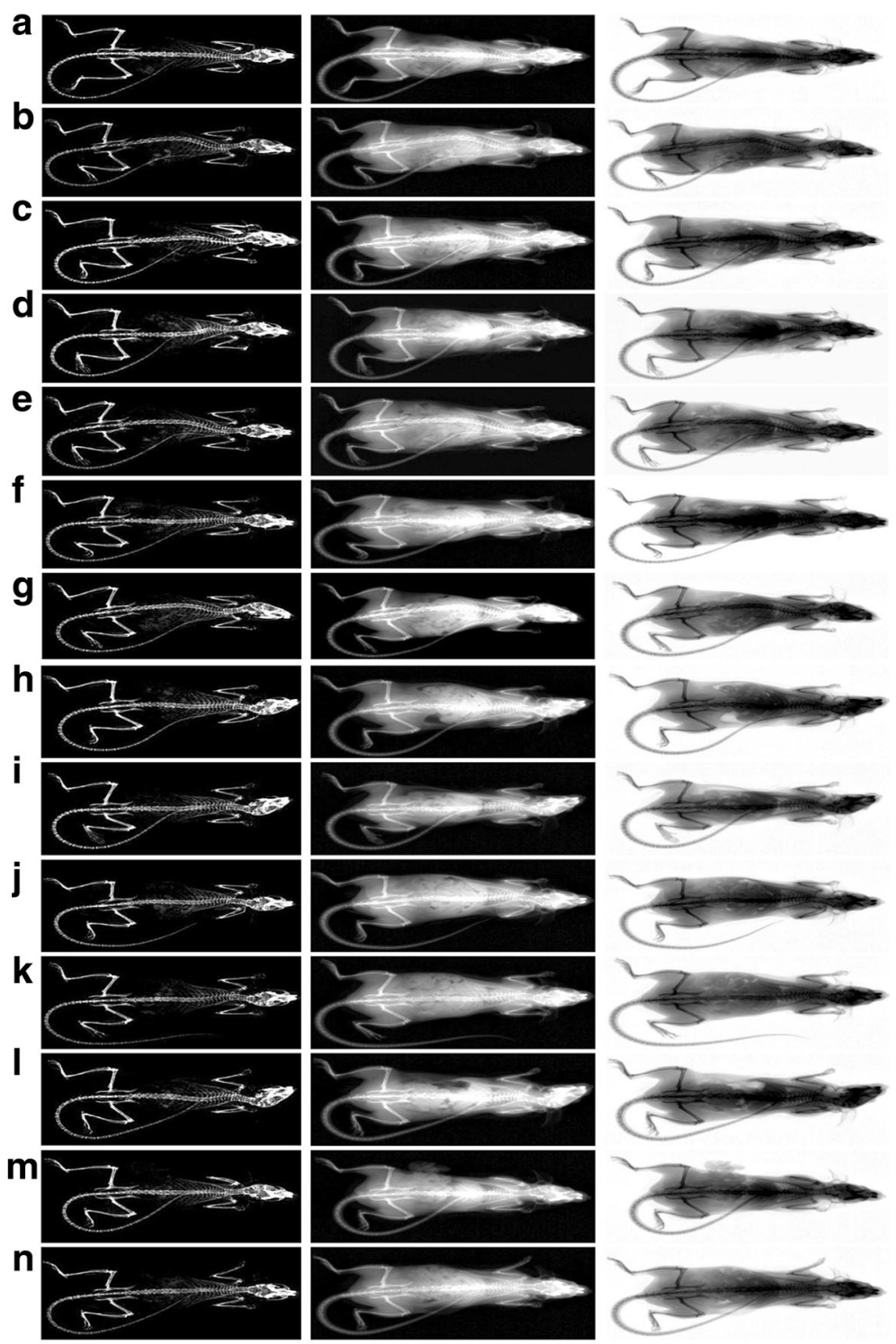

Fig. 4 Representative whole body DEXA images, taken from sham-operated and OVX mice. $\mathbf{a}=$ Sham-operated and distilled water administered sham vehicle control mice. $\mathbf{b}=$ Distilled water administered OVX control mice. $\mathbf{c}=\mathrm{RES} 2.5 \mathrm{mg} / \mathrm{kg}$ orally administered OVX mice. $\mathbf{d}=\mathrm{EAP}$ single formula $200 \mathrm{mg} / \mathrm{kg}$ orally administered OVX mice. e = TM single formula $200 \mathrm{mg} / \mathrm{kg}$ orally administered OVX mice. $\mathbf{f}=$ EAP:TM 1:1 (g/g) mixed formula $200 \mathrm{mg} / \mathrm{kg}$ orally administered OVX mice. $\mathbf{g}=$ EAP:TM 1:3 (g/g) mixed formula $200 \mathrm{mg} / \mathrm{kg}$ orally administered OVX mice. $\mathbf{h}=$ EAP:TM 1:5 (g/g) mixed formula $200 \mathrm{mg} / \mathrm{kg}$ orally administered OVX mice. $\mathbf{i}=$ EAP:TM 1:7 (g/g) mixed formula $200 \mathrm{mg} / \mathrm{kg}$ orally administered OVX mice. $\mathbf{j}=$ EAP:TM 1:9 ( $/ \mathrm{g}$ ) mixed formula $200 \mathrm{mg} / \mathrm{kg}$ orally administered OVX mice. $\mathbf{k}=$ EAP:TM 3:1 $(\mathrm{g} / \mathrm{g})$ mixed formula $200 \mathrm{mg} / \mathrm{kg}$ orally administered OVX mice. I = EAP:TM 5:1 (g/g) mixed formula 200 mg/kg orally administered OVX mice. $\mathbf{m}$ = EAP:TM 7:1 (g/g) mixed formula 200 mg/kg orally administered OVX mice. $\mathbf{n}=$ EAP:TM 9:1 (g/g) mixed formula $200 \mathrm{mg} / \mathrm{kg}$ orally administered OVX mice. OVX: Bilateral ovariectomy; RES: Risedronate sodium; EAP: Exopolymers purified from A. pullulans SM2001; TM: T. morbifera leaf extracts; (EAP:TM): Mixed formula consisted of EAP and TM $(g / g)$. DEXA: Dual-energy $x$-ray absorptionmetry

and osteoblast differentiation has helped in the design of trials to develop anabolic agents [7].

T. morbifera has traditionally been used as an ingredient in preparing medicine and tea for various pharmacological purposes [16-18]. The bone-preserving properties of exopolysaccharide (EAP) have been potentiated by combining it with other active agents [47-49].
Therefore, we expected that appropriate combinations of EAP and TM would demonstrate promising synergistic anti-osteoporotic activities due to the increased availability of the bioactive substances. During this experiment, we used bilateral OVX mice, a renowned rodent model for studying human osteoporosis [7-9], to observe the synergistic anti-osteoporotic potential of mixtures 
Table 4 Histopathology and histomorphometry of the femur in sham-operated and OVX mice: Trabecular Bones

\begin{tabular}{|c|c|c|c|c|}
\hline \multirow{2}{*}{$\begin{array}{l}\text { Items } \\
\text { Groups }\end{array}$} & \multicolumn{4}{|c|}{ Left femur tissues } \\
\hline & TV/BV & Tbn & $\mathrm{Tbl}$ & Tbt \\
\hline \multicolumn{5}{|l|}{ Controls } \\
\hline Sham & $39.33 \pm 5.16$ & $18.63 \pm 2.56$ & $967.87 \pm 131.16$ & $68.48 \pm 10.39$ \\
\hline ovx & $11.33 \pm 2.10^{\mathrm{e}}$ & $3.38 \pm 1.19^{\mathrm{e}}$ & $318.15 \pm 76.18^{\mathrm{a}}$ & $35.91 \pm 10.13^{\mathrm{e}}$ \\
\hline \multicolumn{5}{|c|}{ Reference (2.5 mg/kg) } \\
\hline RES & $43.99 \pm 7.02^{9}$ & $27.50 \pm 5.53^{\mathrm{eg}}$ & $828.28 \pm 109.33^{\mathrm{ab}}$ & $36.51 \pm 10.81^{\mathrm{e}}$ \\
\hline \multicolumn{5}{|c|}{ Single formula (200 mg/kg) } \\
\hline EAP & $24.75 \pm 2.46^{\mathrm{eg}}$ & $10.50 \pm 1.60^{\mathrm{eg}}$ & $594.88 \pm 94.79^{\mathrm{ab}}$ & $49.42 \pm 2.60^{\mathrm{eg}}$ \\
\hline TM & $22.77 \pm 3.11^{\mathrm{eg}}$ & $8.75 \pm 2.96^{\mathrm{eg}}$ & $656.09 \pm 127.21^{\mathrm{ab}}$ & $48.86 \pm 3.98^{\mathrm{eg}}$ \\
\hline \multicolumn{5}{|c|}{ Mixed formula - EAP:TM (200 mg/kg) } \\
\hline $1: 1$ & $24.38 \pm 3.73^{\mathrm{eg}}$ & $9.88 \pm 2.23^{\mathrm{eg}}$ & $551.50 \pm 64.08^{\mathrm{ab}}$ & $48.70 \pm 5.40^{\text {fh }}$ \\
\hline $1: 3$ & $23.68 \pm 3.09^{\mathrm{eg}}$ & $10.25 \pm 1.49^{\mathrm{eg}}$ & $647.64 \pm 147.56^{\mathrm{ab}}$ & $49.76 \pm 7.89^{\mathrm{eh}}$ \\
\hline $1: 5$ & $22.41 \pm 3.53^{\mathrm{eg}}$ & $9.63 \pm 1.85^{\mathrm{eg}}$ & $635.86 \pm 99.62^{\mathrm{ab}}$ & $52.72 \pm 10.21^{\mathrm{ec}}$ \\
\hline $1: 7$ & $23.39 \pm 3.11^{\mathrm{eg}}$ & $9.38 \pm 1.92^{\mathrm{eg}}$ & $646.56 \pm 62.11^{\mathrm{ab}}$ & $49.70 \pm 5.97^{\mathrm{eg}}$ \\
\hline 1:9 & $23.66 \pm 3.97^{\mathrm{eg}}$ & $10.88 \pm 2.03^{\mathrm{eg}}$ & $623.38 \pm 86.57^{\mathrm{ab}}$ & $52.38 \pm 8.86^{\mathrm{eg}}$ \\
\hline $3: 1$ & $35.42 \pm 4.00^{g i j}$ & $17.88 \pm 1.96^{\mathrm{gij}}$ & $913.57 \pm 151.07^{\mathrm{bcd}}$ & $61.78 \pm 6.26^{\text {hij }}$ \\
\hline $5: 1$ & $25.06 \pm 2.44^{\mathrm{eg}}$ & $10.13 \pm 1.25^{\mathrm{eg}}$ & $663.59 \pm 89.99^{\mathrm{ab}}$ & $50.78 \pm 6.69^{e g}$ \\
\hline $7: 1$ & $24.39 \pm 2.83^{\mathrm{eg}}$ & $10.00 \pm 2.00^{\mathrm{eg}}$ & $633.02 \pm 77.63^{\mathrm{ab}}$ & $50.30 \pm 6.14^{e g}$ \\
\hline $9: 1$ & $23.79 \pm 2.56^{\mathrm{eg}}$ & $10.63 \pm 2.67^{\mathrm{eg}}$ & $600.25 \pm 96.45^{\mathrm{ab}}$ & $48.45 \pm 4.79^{e g}$ \\
\hline
\end{tabular}

OVX Bilateral ovariectomy, RES Risedronate sodium, EAP Exopolymers purified from A. pullulans SM2001, TM T. morbifera leaf extracts, (EAP:TM) Mixed formula consisted of EAP and TM $(g / g), T V / B V$ Trabecular bone volume (\%), Tbn Trabecular bone number (Numbers/epiphyseal), Tbl Trabecular bone length (Longitudinal thickness; $\mu \mathrm{m})$, Tbt Trabecular bone thickness (Cross thickness; $\mu \mathrm{m})$

Values are expressed mean \pm S.D. of eight mice

${ }^{a} p<0.01$ as compared with sham control by LSD test

${ }^{b} p<0.01$ as compared with OVX control by LSD test

$c_{p}<0.01$ as compared with EAP single formula treated mice by LSD test

${ }^{d} p<0.01$ as compared with TM single formula treated mice by LSD test

${ }^{e} p<0.01$ and ${ }^{f} p<0.05$ as compared with sham control by MW test

${ }^{9} p<0.01$ and ${ }^{\mathrm{h}} p<0.05$ as compared with OVX control by MW test

i $p<0.01$ as compared with EAP single formula treated mice by MW test

${ }^{\mathrm{j}} p<0.01$ as compared with TM single formula treated mice by MW test

containing different proportions of EAP and TM compared with that of the single formulation of each herbal extract. The EAP:TM mixtures in the present study, significantly $(p<0.01$ or $p<0.05)$ increased anti-osteoporotic activity compared to single formulations of EAP or TM, providing evidence for the synergistic effects of combining these two herbal extracts.

OVX mice showed noticeable increases in body weight, weight gain, and serum osteocalcin levels, as well as decreases in serum bALP activity, femur wet, dry, and ash weights, femur $\mathrm{Ca}$ and IP contents, BMD, and strength as compared to sham vehical control. In addition, decreases in all histomorphometric indices indicated reduction in bone mass and structure, and increases in resorption indices in the femur of OVX controls suggested increases in bone turnover and decreases in bone formation, which are associated with estrogen-deficient osteoporosis. However, these OVX-induced estrogen-deficient osteoporotic signs relating to decreases in bone formation and increases in bone turnover were considerably inhibited by 35 days of continuous oral application with single formulations of EAP or TM, as well as all 9 mixtures of EAP:TM, particularly, EAP:TM (3:1) formulation. These outcomes of this study advocate that the EAP:TM (3:1) mixture synergistically enhanced the distinctive anti-osteoporotic effects of the single formulations, likely due to the increased availability of the bioactive substances.

The results of the present study were comparable to those of RES $(2.5 \mathrm{mg} / \mathrm{kg})$ treatment in this experiment, which suggest that the EAP:TM formulation 3:1 might act as a potent new agent for curing osteoporosis in menopausal women. Although RES 2.5 also ameliorated decreases in femur BMD, femur strength, and trabecular bone architectures induced by estrogen-deficient OVX (through inhibition of bone turnover), it did not critically affect bone formation. The observed serum bALP activity and cortical and trabecular bone thickness were consistent with previously reported results $[14,15]$. In 
Table 5 Histopathology and histomorphometry of the femur in sham-operated and OVX mice: Cortical Bones and Osteoclast Cells

\begin{tabular}{|c|c|c|c|}
\hline \multirow{2}{*}{$\begin{array}{l}\text { Items } \\
\text { Groups }\end{array}$} & \multicolumn{3}{|l|}{ Left femur tissues } \\
\hline & $\mathrm{Cbt}$ & Ocn & OS/BS \\
\hline \multicolumn{4}{|l|}{ Controls } \\
\hline Sham & $305.93 \pm 46.58$ & $3.00 \pm 1.31$ & $3.70 \pm 1.94$ \\
\hline ovx & $171.11 \pm 17.15^{a}$ & $19.63 \pm 2.50^{\mathrm{a}}$ & $25.29 \pm 6.10^{\mathrm{a}}$ \\
\hline \multicolumn{4}{|c|}{ Reference $(2.5 \mathrm{mg} / \mathrm{kg})$} \\
\hline RES & $170.51 \pm 11.52^{\mathrm{a}}$ & $20.25 \pm 4.53^{\mathrm{a}}$ & $10.09 \pm 1.86^{\mathrm{ab}}$ \\
\hline \multicolumn{4}{|c|}{ Single formula $(200 \mathrm{mg} / \mathrm{kg})$} \\
\hline EAP & $196.82 \pm 12.34^{\mathrm{ab}}$ & $13.88 \pm 2.36^{\mathrm{ab}}$ & $15.53 \pm 2.37^{\mathrm{ab}}$ \\
\hline TM & $188.84 \pm 9.85^{\mathrm{ac}}$ & $13.13 \pm 2.10^{\mathrm{ab}}$ & $14.48 \pm 3.30^{\mathrm{ab}}$ \\
\hline \multicolumn{4}{|c|}{ Mixed formula - EAP:TM (200 mg/kg) } \\
\hline $1: 1$ & $195.02 \pm 9.43^{\mathrm{ab}}$ & $13.50 \pm 1.77^{\mathrm{ab}}$ & $15.20 \pm 1.71^{\mathrm{ab}}$ \\
\hline $1: 3$ & $191.78 \pm 9.42^{\mathrm{ac}}$ & $13.25 \pm 3.15^{\mathrm{ab}}$ & $14.79 \pm 4.39^{\mathrm{ab}}$ \\
\hline $1: 5$ & $189.98 \pm 8.23^{\mathrm{ac}}$ & $13.75 \pm 1.91^{\mathrm{ab}}$ & $16.18 \pm 1.78^{\mathrm{ab}}$ \\
\hline $1: 7$ & $190.90 \pm 7.34^{\mathrm{ac}}$ & $12.50 \pm 2.45^{\mathrm{ab}}$ & $14.86 \pm 2.38^{\mathrm{ab}}$ \\
\hline $1: 9$ & $190.56 \pm 10.85^{\mathrm{ac}}$ & $13.13 \pm 1.73^{\mathrm{ab}}$ & $14.93 \pm 2.49^{\mathrm{ab}}$ \\
\hline $3: 1$ & $236.15 \pm 33.30^{\text {abde }}$ & $6.63 \pm 1.41^{\text {abde }}$ & $7.18 \pm 1.41^{\text {abde }}$ \\
\hline $5: 1$ & $194.38 \pm 10.32^{\mathrm{ab}}$ & $12.50 \pm 1.60^{\mathrm{ab}}$ & $13.91 \pm 2.35^{\mathrm{ab}}$ \\
\hline $7: 1$ & $194.87 \pm 10.65^{\mathrm{ab}}$ & $12.25 \pm 2.71^{\mathrm{ab}}$ & $14.02 \pm 3.30^{\mathrm{ab}}$ \\
\hline $9: 1$ & $196.31 \pm 10.93^{\mathrm{ab}}$ & $13.25 \pm 2.05^{\mathrm{ab}}$ & $15.14 \pm 1.73^{\mathrm{ab}}$ \\
\hline
\end{tabular}

OVX Bilateral ovariectomy, RES Risedronate sodium, EAP Exopolymers purified from A. pullulans SM2001, TM T. morbifera leaf extracts, (EAP:TM) Mixed formula consisted of EAP and TM $(g / g)$, Cbt Cortical bone thickness (Cross thickness; $\mu \mathrm{m}$ ), Ocn Osteoclast cell number (Numbers/epiphyseal), OS/BS Osteoclast cell surface/bone surface (\%)

Values are expressed mean \pm S.D. of eight mice

${ }^{a} p<0.01$ as compared with sham control by MW test

${ }^{\mathrm{b}} p<0.01$ and ${ }^{c} p<0.05$ as compared with OVX control by MW test

${ }^{d} p<0.01$ as compared with EAP single formula treated mice by MW test

${ }^{e} p<0.01$ as compared with TM single formula treated mice by MW test

one condition of the current experiment, EAP:TM 3:1 showed slightly lower antiresorptive effects compared to RES $(2.5 \mathrm{mg} / \mathrm{kg})$. However, EAP:TM 3:1 exhibited effects on bone formation, which were not observed with RES $2.5 \mathrm{mg} / \mathrm{kg}$ treatment. Hence, EAP:TM 3:1 demonstrated favorable anti-osteoporotic effects in OVX mice that were comparable to RES $(2.5 \mathrm{mg} / \mathrm{kg})$ treatment.

During the present study, the observed increases in weight gain and body weights in the OVX groups were distinct signs of estrogen-deficient condition in the tested mice, however the differences were inconsistent. Lorden and Caudle (1986) as well as Bain et al. (1993) reported increases in body weight after OVX $[55,56]$, while other studies failed to report the same [57, 58]. Generally, decreases in body weight or weight gain have been considered a sign of toxicity in normal states but in disease states, such as obesity, it is regarded as a favorable sign [7,9]. During this study, noteworthy decreases in bodyweight gains were observed in all mice treated with EAP:TM formulations, particularly in EAP:TM 3:1-formulation.

Changes in bone weight are not considered a significant parameter for detecting the efficacy of an anti-osteoporotic agent [59]. However, increases in relative bone weights have been deliberated as a valued indicator of anti-osteoporotic property [7, 9]. In the present study, OVX mice showed noteworthy decreases in femur absolute and relative dry and ash weights, as well as relative wet-weights. Conversely, marked enhancements in femur dry, wet, and ash weights were noticed in mice treated with all test materials, including RES $(2.5 \mathrm{mg} / \mathrm{kg})$. In particular, EAP:TM 3:1-formulation displayed significant increase in femur absolute and relative ash and dry weights, as well as wet-weights. Hence, the inhibitory effects of TM or EAP single formulations on OVX-induced decreases of bone weights were synergistically enhanced by the EAP:TM 3:1 combination.

Variations in the use of animals, and study design have been reported by different studies. There also exist disagreements on the interpretation of bone turnover and formation. Despite these issues, serum bALP and osteocalcin levels are normally considered as acceptable indicators of bone formation and turnover, respectively [7, 9, 60-62]. In this study, OVX-control groups showed a significant decrease in serum bALP activity and a significant increase in serum osteocalcin levels as compared with the sham-control groups. However, all EAP:TM single or mixed formulations and especially, mice treated with EAP:TM 3:1-formualtion showed increases in serum bALP activity and decreases in osteocalcin levels.

Bone mineral content significantly decrease as osteoporosis progresses [7, 9]. Specifically, IP and Ca decrease most dramatically; however, $\mathrm{Ca} / \mathrm{IP}$ ratios do not change because of the simultaneous reduction in both IP and Ca concentration $[7,9,63,64]$. In the current analysis, significant decreases in femur $\mathrm{Ca}$ and IP concentrations were observed in OVX control. Nevertheless, marked increases in femur $\mathrm{Ca}$ and IP levels were noticed in all mice administered the test materials, including EAP:TM $1: 1$, compared with that in OVX control mice. In particular, EAP:TM 3:1-treated mice also revealed marked increases in $\mathrm{Ca}$ and IP contents in the right femur.

BMD, a well-acknowledged indicator of fluctuations in bone quality under clinical settings, decreases in osteoporosis, irrespective of the cause $[7,9,65,66]$. BMD has provided useful predictive information on the efficacy of anti-osteoporotic agents [66], and bone quality diagnostic profiles for clinical research [65]. BMD and bone strength significantly reduces in osteoporosis irrespective of the causes $[7,9,65,66]$. In this study, a significant decrease in femur mean BMD and total body was noticed in OVX control groups. However, test material-administered 


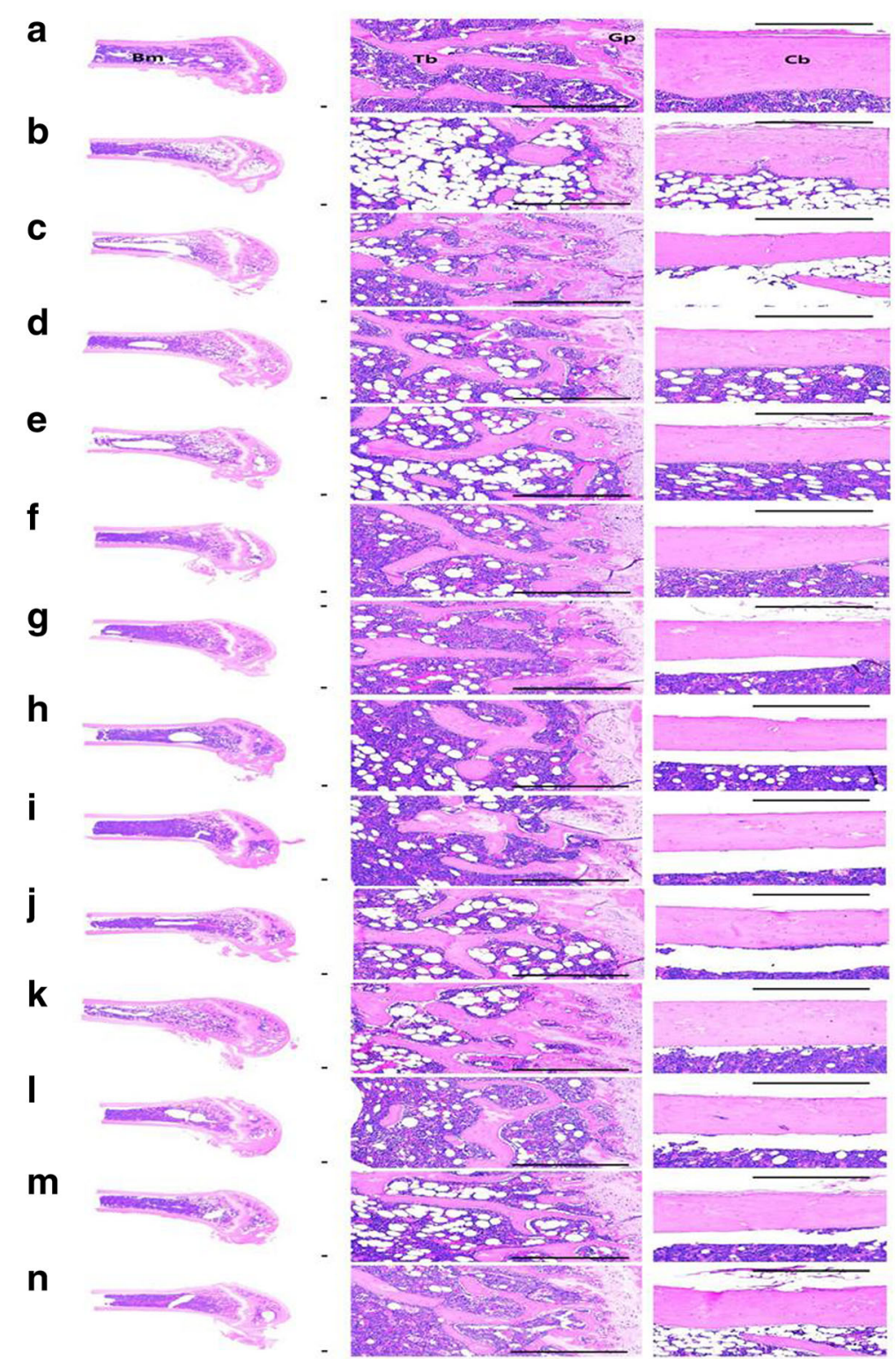

Fig. 5 Representative histological profiles of the left femur, taken from sham-operated and OVX mice. $\mathbf{a}=$ Sham-operated and distilled water administered sham vehicle control mice. $\mathbf{b}=$ Distilled water administered OVX control mice. $\mathbf{c}=$ RES $2.5 \mathrm{mg} / \mathrm{kg}$ orally administered OVX mice. $\mathbf{d}=$ EAP single formula $200 \mathrm{mg} / \mathrm{kg}$ orally administered OVX mice. $\mathbf{e}=$ TM single formula $200 \mathrm{mg} / \mathrm{kg}$ orally administered OVX mice. $\mathbf{f}=$ EAP:TM 1:1 (g/g) mixed formula $200 \mathrm{mg} / \mathrm{kg}$ orally administered OVX mice. $\mathbf{g}=$ EAP:TM 1:3 (g/g) mixed formula $200 \mathrm{mg} / \mathrm{kg}$ orally administered OVX mice. $\mathbf{h}=$ EAP:TM 1:5 (g/g) mixed formula $200 \mathrm{mg} / \mathrm{kg}$ orally administered OVX mice. $\mathbf{i}=$ EAP:TM 1:7 ( $\mathrm{g} / \mathrm{g})$ mixed formula $200 \mathrm{mg} / \mathrm{kg}$ orally administered OVX mice. $\mathbf{j}=$ EAP:TM 1:9 $(\mathrm{g} / \mathrm{g})$ mixed formula $200 \mathrm{mg} / \mathrm{kg}$ orally administered OVX mice. $\mathbf{k}=$ EAP:TM 3:1 $(\mathrm{g} / \mathrm{g})$ mixed formula $200 \mathrm{mg} / \mathrm{kg}$ orally administered OVX mice. I =EAP:TM 5:1 (g/g) mixed formula 200 mg/kg orally administered OVX mice. m=EAP:TM 7:1 (g/g) mixed formula 200 mg/kg orally administered OVX mice. $\mathbf{n}=$ EAP:TM 9:1 (g/g) mixed formula $200 \mathrm{mg} / \mathrm{kg}$ orally administered OVX mice. OVX: Bilateral ovariectomy; RES: Risedronate sodium; EAP: Exopolymers purified from A. pullulans SM2001; TM: T. morbifera leaf extracts; (EAP:TM): Mixed formula consisted of EAP and TM (g/g). Cb: cortical bone; Tb: trabecular bone; Bm: bone marrow; Gp: growth plate. All Hematoxylin and eosin stain. Scale bars $=300 \mu \mathrm{m}$

groups including those treated with the EAP single formulation, showed noteworthy increases in femur FL and mean BMD, and total body. Especially, EAP:TM 3:1 $(\mathrm{g} / \mathrm{g})$-treated mice showed significant enhancement in femur mean BMD, total body and femur strength as compared to those of EAP or TM single formulations.
The changes in bone morphology can be easily observed by microscopic analysis [7, 9, 67]. The histological profiles of cortical and trabecular bones mainly alter in osteoporotic animals. Furthermore, the impact of numerous anti-osteoporotic substances has been estimated on bone histology [68]. Some histomorphometric 
indices of bone masses noticeably decrease whereas, bone resorption indices increase; this kind of measurements have been found to be good predictors of the efficacy of anti-osteoporotic agents $[9,68-70]$. In this study, OVXcontrol groups showed typical osteoporotic histological profiles, as evidenced by dramatic reduction in cortical and trabecular bone mass, as well as enhancement in connective tissue of the cortical bone. Although administration of RES repressed trabecular bone loss, it did not affect cortical bone mass. Whereas, significant enhancement in the cortical and trabecular bone structure and mass was observed in all groups administered with the test materials including single formulations. This could be attributed to the inhibition of osteoclast cell activity by EAP and TM. In particular, EAP:TM 3:1-treated mice showed greater inhibition of the histopathological reduction in osteoclast activation and femur bone mass compared to mice administered with the TM or EAP single formulations.

The findings of the present study clearly indicated the favorable synergistic effects of EAP:TM (3:1) formulation on bone turnover and formation in OVX-induced metabolic disorder. No remarkable variation in body weight, body weight gain, and femur $\mathrm{Ca} / \mathrm{IP}$ ratio was detected in OVX control groups as well as in groups administered with the test materials, including RES. Moreover, RES $2.5 \mathrm{mg} / \mathrm{kg}$ significantly decreased serum osteocalcin levels, but had no effect on serum bALP activity.

\section{Conclusions}

In this study, a continuous oral administration of the single and/or combined formulations of EAP and TM significantly inhibited the OVX-induced osteoporotic symptoms i.e., decreased formation and increased turnover of bone. In particular, compared with the single formulations, the EAP:TM (3:1) mixture revealed significantly favorable inhibition of estrogen-deficient osteoporosis indices. In the conditions of the current experiment, EAP:TM (3:1) formulation showed slightly lower antiresorptive effects than RES $2.5 \mathrm{mg} / \mathrm{kg}$; however, EAP:TM 3:1 demonstrated bone formation effects, which were not observed with RES $2.5 \mathrm{mg} / \mathrm{kg}$ treatment. These findings are considered direct and reliable proof that the EAP:TM 3:1 mixed formulation synergistically enhanced the distinct anti-osteoporotic potential of the single EAP or TM formulations, which might be due to the enhanced availability of the bioactive substances. Hence, EAP:TM 3:1 mixture might act as a potent new agent for curing osteoporosis in menopausal women. Although RES $2.5 \mathrm{mg} / \mathrm{kg}$ also favorably ameliorated OVX-induced reductions in femur BMD, femur strength, and trabecular bone architecture through the inhibition of bone turnover, it did not critically affect bone formation (measured by serum bALP and cortical and trabecular bone thickness).

\section{Additional files}

\begin{abstract}
Additional file 1: Raw data on body weight gain in sham-operated and OVX mice. OVX: Bilateral ovariectomy; RES: Risedronate sodium; EAP: Exopolymers purified from A. pullulans SM2001; TM: T. morbifera leaf extracts; (EAP:TM): Mixed formula consisted of EAP and TM $(\mathrm{g} / \mathrm{g})$. Values are expressed mean \pm S.D. of eight mice. *All animals were overnight fasted. (XLSX $12 \mathrm{~kb}$ )

Additional file 2: Raw data on right femur weights of sham-operated and OVX mice. OVX: Bilateral ovariectomy; RES: Risedronate sodium; EAP: Exopolymers purified from A. pullulans SM2001; TM: T. morbifera leaf extracts; (EAP:TM): Mixed formula consisted of EAP and TM $(\mathrm{g} / \mathrm{g})$. Values are expressed mean \pm S.D. of eight mice. (XLSX $32 \mathrm{~kb}$ )
\end{abstract}

Additional file 3: Raw data on serum osteocalcin and bALP levels in sham-operated and OVX mice. OVX: Bilateral ovariectomy; RES: Risedronate sodium; EAP: Exopolymers purified from A. pullulans SM2001; TM: T. morbifera leaf extracts; (EAP:TM): Mixed formula consisted of EAP and TM $(g / g)$. Values are expressed mean \pm S.D. of eight mice. RES was orally administered at a dose level of $2.5 \mathrm{mg} / \mathrm{kg}$. All single and mixed formula consisted of EAP and TM were administered at a dose level of totalized $200 \mathrm{mg} / \mathrm{kg}$ by gastric gavage. (XLSX $15 \mathrm{~kb}$ )

Additional file 4: Raw data on BMD (bone mineral density; total body and right femur). OVX: Bilateral ovariectomy; RES: Risedronate sodium; EAP: Exopolymers purified from A. pullulans SM2001; TM: T. morbifera leaf extracts; (EAP:TM): Mixed formula consisted of EAP and TM $(\mathrm{g} / \mathrm{g})$. Values are expressed mean \pm S.D. of eight mice. (XLSX $15 \mathrm{~kb}$ )

Additional file 5: Raw data on FL (failure load) quantified bone strength. OVX: Bilateral ovariectomy; RES: Risedronate sodium; EAP: Exopolymers purified from A. pullulans SM2001; TM: T. morbifera leaf extracts; (EAP:TM): Mixed formula consisted of EAP and TM $(\mathrm{g} / \mathrm{g})$. Values are expressed mean \pm S.D. of eight mice. (XLSX $13 \mathrm{~kb}$ )

Additional file 6: Raw data on BMC (bone mineral content), Ca and IP. OVX: Bilateral ovariectomy; RES: Risedronate sodium; EAP: Exopolymers purified from A. pullulans SM2001; TM: T. morbifera leaf extracts; (EAP:TM): Mixed formula consisted of EAP and TM $(\mathrm{g} / \mathrm{g})$. Values are expressed mean \pm S.D. of eight mice. $C a=$ Calcium; IP = Inorganic phosphorus. (XLSX $19 \mathrm{~kb})$

Additional file 7: Raw data for Histopathology and Histomorphometry of the femur in sham-operated and OVX mice: Trabecular Bones. OVX: Bilateral ovariectomy; RES: Risedronate sodium; EAP: Exopolymers purified from A. pullulans SM2001; TM: T. morbifera leaf extracts; (EAP:TM): Mixed formula consisted of EAP and TM $(g / g)$. Values are expressed mean \pm S.D. of eight mice. TV/BV = Trabecular bone volume (\%); Tbn = Trabecular bone number (Numbers/epiphyseal); Tbl=Trabecular bone length (Longitudinal thickness; $\mu \mathrm{m})$; Tbt = Trabecular bone thickness (Cross thickness; $\mu \mathrm{m})$. (XLSX $23 \mathrm{~kb}$ )

Additional file 8: Raw data for Histopathology and Histomorphometry of the femur in sham operated and OVX mice: Cortical Bones and Osteoclast Cells. OVX: Bilateral ovariectomy; RES: Risedronate sodium; EAP: Exopolymers purified from A. pullulans SM2001; TM: T. morbifera leaf extracts; (EAP:TM): Mixed formula consisted of EAP and TM $(\mathrm{g} / \mathrm{g})$. Values are expressed mean \pm S.D. of eight mice. $\mathrm{Cbt}=$ Cortical bone thickness (Cross thickness; $\mu \mathrm{m}$ ); Ocn = Osteoclast cell number (Numbers/ epiphyseal); OS/BS = Osteoclast cell surface/bone surface (\%). (XLSX 15 kb)

\section{Abbreviations}

ANOVA: One way analysis of variance; bALP: Bone specific alkaline phosphatase; BMD: Bone mineral density; Ca: Calcium; Cbt: Cortical bone thickness; EAP: Extracellular polymers isolated from Aureobasidium pullulans SM-2001; FL: Failure load; HE: Hematoxylin and eosin; ICR: Institute of Cancer Research; IP: Inorganic phosphorus; LSD: Least-significant differences; MW: Mann-Whitney U; Ocn: Osteoclast cell number; RES: Risedronate sodium; Tbl: Trabecular bone length; Tbn: Trabecular bone number; Tbt: Trabecular bone thickness; TBV: Trabecular bone volume; TM: Textoria morbifera; TV/ BV: Trabecular bone volume (\%) 


\section{Acknowledgements}

Dr. Jae-Suk Choi would like to thanks Chang-Soo Cho for awarding the research grant.

\section{Funding}

This research was financially supported by the Ministry of Trade, Industry and Energy (MOTIE) and Korea Institute for Advancement of Technology (KIAT), Republic of Korea, through the Promoting Regional Specialized Industry (No. R0005614).

\section{Availability of data and materials}

All data generated or analyzed during this study are included in this published article and the primary data has been provided as a supplementary file.

\section{Authors' contributions}

CSC, SBM, SKK, JSC designed the experiment; HSJ, IYK, GWJ, KMIB prepared experimental samples and performed analytic experiments; BHK, DCP, SKK performed animal experiments; HRC, SKK, JSC prepared the manuscript. All authors have gone through and approved the manuscript.

\section{Ethics approval and consent to participate}

All laboratory animals were treated according to the national regulations for the usage and welfare of laboratory animals, and approved by the Institutional Animal Care and Use Committee of Daegu Haany University, Gyeongsan, Gyeongbuk-do, Republic of Korea, prior to animal experiments [Approval No: DHU2016-072; Approved on: August 23, 2016]. In addition, experiments on osteoporosis were conducted based on the United States Food and Drug Administration (FDA) Guidelines for Preclinical Evaluation of Agents Used in The Prevention or Treatment of Postmenopausal Osteoporosis [April 1994, Division of Metabolic and Endocrine Drug Products, USA]

\section{Consent for publication}

Not applicable.

\section{Competing interests}

The authors declare that they have no competing interests.

\section{Publisher's Note}

Springer Nature remains neutral with regard to jurisdictional claims in published maps and institutional affiliations.

\section{Author details \\ ${ }^{1}$ Hurim Hwangchil Co., Ltd, 907-11, Gyeongseo-dearo, Hoengcheon-myeon, Hadong-gun, Gyeongsangnam-do 52320, Republic of Korea. ${ }^{2}$ Glucan Corp., \#305 Marine Bio-Industry Development Centger, 7 Hoenggye-gilllgwang-myeon, Busan 46048, Republic of Korea. ${ }^{3}$ Research Center for Extremophiles and Microbiology, College of Medical and Life Sciences, Silla University, 140, Baegyang-daero 700 beon-gilSasang-gu, Busan 46958, Republic of Korea. ${ }^{4}$ Seafood Research Center, IACF, Silla University, 606, Advanced Seafood Processing Complex, Wonyang-ro, Amnam-dongSeo-gu, Busan 49277, Republic of Korea. ${ }^{5}$ Department of Anatomy and Histology, College of Korean Medicine, Daegu Haany University, 1, Hanuidae-ro, Gyeongsan-si, Gyeongsangbuk-do 38610, Republic of Korea. ${ }^{6}$ Major in Food Biotechnology, Division of Bioindustry, College of Medical and Life Sciences, Silla University, 140, Baegyang-daero 700beon-gilSasang-gu, Busan 46958, Republic of Korea.}

\section{Received: 3 April 2018 Accepted: 25 October 2018} Published online: 06 November 2018

\section{References}

1. Eddy DM, CC J, Cummings SR, Dawson-Hughes B, Lindsay R, Melton LJ, Slemenda CW. Osteoporosis: review of the evidence for prevention, diagnosis, and treatment and cost-effectiveness analysis. Status Report Osteoporosis International. 1998;8(Suppl. 4).

2. Sakai A, Nishida S, Okimoto N, Okazaki Y, Hirano T, Norimura T, Suda T, Nakamura T. Bone marrow cell development and trabecular bone dynamics after ovariectomy in ddy mice. Bone. 1998;23:443-51.
3. Yamaguchi K, Tada M, Tsuji T, Kuramoto M, Uemura D. Suppressive effect of norzoanthamine hydrochloride on experimental osteoporosis in ovariectomized mice. Biol Pharm Bull. 1999;22:920-4.

4. Curtis EM, Moon RJ, Harvey NC, Cooper C. The impact of fragility fracture and approaches to osteoporosis risk assessment worldwide. Bone. 2017;104:29-38.

5. Rodan GA, Martin TJ. Therapeutic approaches to bone diseases. Science. 2000;289:1508-14.

6. Gowen M, Emery JG, Kumar S. Emerging therapies for osteoporosis. Emerging Drugs. 2000;5:1-43.

7. Joo JH, Huh JE, Lee JH, Park DR, Lee Y, Lee SG, Choi S, Lee HJ, Song SW, Jeong Y, Goo Jl, Choi Y, Baek HK, Yi SS, Park SJ, Lee JE, Ku SK, Lee WJ, Lee KI, Lee SY, Bae YS. A novel pyrazole derivative protects from ovariectomy-induced osteoporosis through the inhibition of NADPH oxidase. Sci Rep. 2016;6:22389.

8. Shin HD, Yang KJ, Park BR, Son CW, Jang HJ. Ku SK. Antiosteoporotic effect of Polycan, beta-glucan from Aureobasidium, in ovariectomized osteoporotic mice. Nutrition. 2007;23:853-60

9. Kang SJ, Choi BR, Kim SH, Yi HY, Park HR, Song CH, Ku SK, Lee YJ. Selection of the optimal herbal compositions of red clover and pomegranate according to their protective effect against climacteric symptoms in ovariectomized mice. Nutrients. 2016;8:447.

10. Harris ST, Watts NB, Genant HK, McKeever CD, Hangartner T, Keller M, Chesnut CH 3rd, Brown J, Eriksen EF, Hoseyni MS, Axelrod DW, Miller PD. Effects of risedronate treatment on vertebral and nonvertebral fractures in women with postmenopausal osteoporosis: a randomized controlled trial. Vertebral efficacy with Risedronate therapy (VERT) study group. JAMA. 1999:282:1344-52.

11. Boonen S, Haentjens $P$, Vandenput $L$, Vanderschueren D. Preventing osteoporotic fractures with antiresorptive therapy: implications of microarchitectural changes. J Intern Med. 2004;255:1-12.

12. Bae DC, Stein BS. The diagnosis and treatment of osteoporosis in men on androgen deprivation therapy for advanced carcinoma of the prostate. J Urol. 2004;172:2137-44.

13. Roux C, Seeman E, Eastell R, Adachi J, Jackson RD, Felsenberg D, Songcharoen S, Rizzoli R, Di Munno O, Horlait S, Valent D, Watts NB. Efficacy of risedronate on clinical vertebral fractures within six months. Curr Med Res Opin. 2004:20:433-9.

14. Ito M, Nishida A, Aoyagi K, Uetani M, Hayashi K, Kawase M. Effects of risedronate on trabecular microstructure and biomechanical properties in ovariectomized rat tibia. Osteoporos Int. 2005;16:1042-8.

15. Nam SH, Jeong JH, Che X, Lim KE, Nam H, Park JS, Choi JY. Topically administered Risedronate shows powerful anti-osteoporosis effect in ovariectomized mouse model. Bone. 2012;50:149-55.

16. Kim RW, Lee SY, Kim SG, Heo YR, Son MK. Antimicrobial, antioxidant and cytotoxic activities of Dendropanax morbifera Léveille extract for mouthwash and denture cleaning solution. J Adv Prosthodont. 2016b;8:172-80.

17. Kim W, Yim HS, Yoo DY, Jung HY, Kim JW, Choi JH, Yoon YS, Kim DW, Hwang IK. Dendropanax morbifera Léveille extract ameliorates cadmiuminduced impairment in memory and hippocampal neurogenesis in rats. BMC Complement Altern Med. 2016c;16:452.

18. Kim JM, Park SK, Guo TJ, Kang JY, Ha JS, Lee d S, Lee U, Heo HJ. Antiamnesic effect of Dendropanax morbifera via JNK signaling pathway on cognitive dysfunction in high-fat diet-induced diabetic mice. Behav Brain Res. 2016a;312:39-54.

19. Lee SH, Park YS, Hwang B, Kim JH, Lee HY. Screening of immune activation activities in the leaves of Dendropanax morbifera lev. Korean J Med Crop Sci. 2002;10:109-15

20. Hyun TK, Kim MO, Lee H, Kim Y, Kim E, Kim JS. Evaluation of anti-oxidant and anti-cancer properties of Dendropanax morbifera Léveille. Food Chem. 2013;141:1947-55.

21. Moon HI. Antidiabetic effects of dendropanoxide from leaves of Dendropanax morbifera Leveille in normal and streptozotocin-induced diabetic rats. Hum Exp Toxicol. 2011:30:870-5.

22. Chung IM, Kim MY, Park WH, Moon HI. Antiatherogenic activity of Dendropanax morbifera essential oil in rats. Pharmazie. 2009;64:547-9.

23. Chung IM, Song HK, Kim SJ, Moon HI. Anticomplement activity of polyacetylenes from leaves of Dendropanax morbifera Leveille. Phytother Res. 2011;25:784-6.

24. Yang DU, Siddiqi MH, Ahn S, Yang DC. The effects of extract from Dendropanax morbifera on the osteoporosis and osteoarthritis. Proceeding of 2015 KFN international symposium and annual meeting, phytonutrients and Healtht foods. Aug. 24-26, Alpensia convention center. Korea: Pyeongchang; 2015. p. 119. 
25. Yang DU, Siddiqi MH, Ahn S, Kang S, Noh HY, Yang DC. In vitro evaluation of the potential therapeutic role of Dendropanax morbifera extract in ameliorating osteoporosis and resultant bone impairment using MC3T3-E1 cells. In Vitro Cell Dev Biol. 2018:54:346-54.

26. Kim EH, Jo CS, Ryu SY, Kim SH, Lee JY. Anti-osteoclastogenic diacetylenic components of Dendropanax morbifera. Arch Pharm Res. 2018;41:506-12.

27. Jeong BS, Jo JS, Pyo BS, Hwang B. Studies on the distribution of Dendropanax morbifera and component analysis of the golden lacquer. Korean Soc Biotechnol Bioeng J. 1995;10:393-400.

28. Tzianabos AO. Polysaccharide immunomodulators as therapeutic agents: structural aspects and biologic function. Clin Microbiol Rev. 2000;13: 523-33.

29. Bashir KMI, CJS. Clinical and Physiological perspectives of b-glucans: the past, present and future. Int J Mol Sci. 1906;18(9).

30. Lotzová E, Gutterman JU. Effect of glucan on natural killer (NK) cells: further comparison between NK cell and bone marrow effector cell activities. J Immunol. 1979;123:607-11.

31. Hofer M, Pospísil M. Glucan as stimulator of hematopoiesis in normal and gamma-irradiated mice. A survey of the authors' results. Int J Immunopharmacol. 1997;19:607-9.

32. Lee JN, Lee DY, Ji IH, Kim GE, Kim HN, Sohn J, Kim S, Kim CW. Purification of soluble beta-glucan with immune-enhancing activity from the cell wall of yeast. Biosci Biotechnol Biochem. 2001;65:837-41.

33. Benach JL, Habicht GS, Holbrook TW, Cook JA. Glucan as an adjuvant for a murine Babesia microti immunization trial. Infect Immun. 1982;35: 947-51.

34. Seo HP, Kim JM, Shin HD, Kim TK, Chang HJ, Park BR, Lee JW. Production of B-1,3/1,6-glucan by Aureobasidium pullulans SM-2001. Korean J Bitechnol Bioeng. 2002;17:376-80.

35. Jung MY, Kim JW, Kim KY, Choi SH, Polycan KSK. A $\beta$-glucan from Aureobasidium pullulans SM-2001, mitigates ovariectomy-induced osteoporosis in rats. Exp Ther Med. 2016;12:1251-62.

36. Lee HS, Cho HR, Moon SB, Shin HD, Yang KJ, Park BR, Jang HJ, Kim LS. Ku SK. Effect of $\beta$-glucan from Aureobsidium pullulans on rat rib fracture healing. Lab Anim Res. 2008a;24:39-44.

37. Kim HD, Cho HR, Moon SB, Shin HD, Yang KJ, Park BR, Jang HJ, Kim LS, Lee HS. Ku SK. Effects of $\beta$-glucan from Aureobasidum pullulans on acute inflammation in mice. Arch Pharm Res. 2007;30:323-8.

38. Kim HD, Cho HR, Moon SB, Shin HD, Yang KJ, Park BR, Jang HJ, Kim LS, Lee HS, Ku SK. Effect of exopolymers from Aureobasidum pullulans on formalin-induced chronic paw inflammation in mice. J Microbiol Biotechnol. 2006;16:1954-60.

39. Yoon HS, Kim JW, Cho HR, Moon SB, Shin HD, Yang KJ, Lee HS, Kwon YS. Ku SK. Immunomodulatory effects of Aureobasidium pullulans SM-2001 exopolymers on the cyclophosphamide-treated mice. J Microbiol Biotechnol. 2010;20:438-45.

40. Ku SK, Lee YJ, Lee SD, Cho HR, Moon SB, Kim KY, Kwon YS, Kim JW. Nephroprotective effect of Polycan on acute renal failure induced by cisplatin in rats. ISRN Vet Sci. 2012b;2012:862104.

41. Ku SK, Kim JW, Cho HR, Kim KY, Min YH, Park JH, Kim JS, Park JH, Seo BI, Roh SS. Effect of $\beta$-glucan originated from Aureobasidium pullulans on asthma induced by ovalbumin in mouse. Arch Pharm Res. 2012a;35:1073-81.

42. Kim JW, Cho HR. Ku SK. Efficacy test of Polycan, a beta-glucan originated from Aureobasidium pullulans SM-2001, on anterior cruciate ligament transection and partial medial meniscectomy-induced-osteoarthritis rats. J Microbiol Biotechnol. 2012a;22:274-82.

43. Kim YS, Kang SJ, Kim JW, Cho HR, Moon SB, Kim KY, Lee HS, Han CH, Ku SK, Lee YJ. Effects of Polycan, a $\beta$-glucan, on experimental periodontitis and alveolar bone loss in Sprague-Dawley rats. J Periodontal Res. 2012b;47:800-10.

44. Lee HS, Kim HH. Ku SK. Hepatoprotective effects of Artemisiae capillaris herba and Picrorrhiza rhizoma combinations on carbon tetrachlorideinduced subacute liver damage in rats. Nutr Res. 2008b;28:270-7.

45. Lee JE, Kang SJ, Choi SH, Song CH, Lee YJ. Ku SK. Fermentation of green tea with $2 \%$ Aquilariae lignum increases the anti-diabetic activity of green tea aqueous extracts in the high fat-fed mouse. Nutrients. 2015;7:9046-78.

46. Kang SJ, Choi BR, Kim SH, Yi HY, Park HR, Kim DC, Choi SH, Han CH, Park SJ, Song CH, Ku SK, Lee YJ. Dried pomegranate potentiates anti-osteoporotic and anti-obesity activities of red clover dry extracts in ovariectomized rats. Nutrients. 2015;7:2622-47.

47. Choi JS, Kim JW, Kim KY, Cho HR, Choi IS. Ku SK. Antiosteoporotic effects of Polycan in combination with calcium lactate-gluconate in ovariectomized rats. Exp Ther Med. 2014;8:957-67.
48. Choi JS, Shin HS, Kim KY, Ku SK, Choi IS, Kim JW. Effect of Polycalcium, a mixture of Polycan and calcium lactate-gluconate in a 1:9 weight ratio, on rats with surgery-induced osteoarthritis. Exp Ther Med. 2015;9:1780-90.

49. Park SI, Kang SJ, Han CH, Kim JW, Song CH, Lee SN, Ku SK, Lee YJ. The effects of topical application of Polycal (a 2:98 (g/g) mixture of Polycan and calcium gluconate) on experimental periodontitis and alveolar bone loss in rats. Molecules. 2016;21(4):527.

50. Jämsä T, Jalovaara P, Peng Z, Väänänen HK, Tuukkanen J. Comparison of three-point bending test and peripheral quantitative computed tomography analysis in the evaluation of the strength of mouse femur and tibia. Bone. 1998;23:155-61.

51. Levene A. Pathological factors influencing excision of tumours in the head and neck. Part I Clin Otalary. 1981;6:145-51.

52. Ludbrook J. Update: microcomputer statistics packages. A personal view. Clin Exp Pharmacol Physiol. 1997;24:294-6.

53. Kang SJ, Lee JE, Lee EK, Jung DH, Song CH, Park SJ, Choi SH, Han CH, Ku SK, Lee YJ. Fermentation with Aquilariae lignum enhances the anti-diabetic activity of green tea in type II diabetic db/db mouse. Nutrients. 2014;6: 3536-71.

54. Manolagas SC, Kousteni S, Jilka RL. Sex steroids and bone. Recent Prog Horm Res. 2002;57:385-409.

55. Lorden JF, Caudle A. Behavioral and endocrinological effects of single injections of monosodium glutamate in the mouse. Neurobehav Toxicol Teratol. 1986;8:509-19.

56. Bain SD, Bailey MC, Celino DL, Lantry MM, Edwards MW. High-dose estrogen inhibits bone resorption and stimulates bone formation in the ovariectomized mouse. J Bone Miner Res. 1993;8:435-42.

57. Sandstedt J, Tornell J, Norjavaara E, Isaksson OG, Ohlsson C. Elevated levels of growth hormone increase bone mineral content in normal young mice, but not in ovariectomized mice. Endocrinology. 1996;137:3368-74.

58. Andersson N, Lindberg MK, Ohlsson C, Andersson K, Ryberg B. Repeated in vivo determinations of bone mineral density during parathyroid hormone treatment in ovariectomized mice. J Endocrinol. 2001;170:529-37.

59. Yamamoto M, Fisher JE, Gentile M, Seedor JG, Leu CT, Rodan SB, Rodan GA. The integrin ligand echistatin prevents bone loss in ovariectomized mice and rats. Endocrinology. 1998;139:1411-9.

60. Ederveen $\mathrm{AG}$, Kloosterboer HJ. Tibolone, a steroid with a tissue-specific hormonal profile, completely prevents ovariectomy-induced bone loss in sexually mature rats. J Bone Miner Res. 1999;14:1963-70.

61. Ke HZ, Foley GL, Simmons HA, Shen V, Thompson DD. Long-term treatment of lasofoxifene preserves bone mass and bone strength and dose not adversely affect the uterus in ovariectomized rats. Endocrinology. 2004;145: 1996-2005.

62. Ismail F, Epstein S, Fallon MD, Thomas SB, Reinhardt TA. Serum bone gla protein and the vitamin $D$ endocrine system in the oophorectomized rat. Endocrinology. 1988;122:624-30.

63. Tarvainen R, Arnala I, Olkkonen H, Lappalainen R, Nevalainen T, Alhava E. Clodronate prevents immobilization osteopenia in rats. Acta Orthop Scand. 1994;65:643-6.

64. Tanaka S, Shimizu M, Debari K, Furuya R, Kawawa T, Sasaki T. Acute effects of ovariectomy on wound healing of alveolar bone after maxillary molar extraction in aged rats. Anat Rec. 2001;262:203-12.

65. Diez F. Guidelines for the diagnosis of osteoporosis by densitometric methods. J Manip Physiol Ther. 2002;25:403-15.

66. Syed Z, Khan A. Bone densitometry: applications and limitations. J Obstet Gynaecol Can. 2002;24:476-84.

67. Heikkinen T, Puolivali J, Tanila H. Effects of long-term ovariectomy and estrogen treatment on maze learning in aged mice. Exp Gerontol. 2004;39: $1277-83$.

68. Jakubas-Przewlocka J, Przewlocki P, Sawicki A. Assessment of changes due to the long-term effect of estrogen and calcium deficiency in the trabecular bone structure in rats. Clin Exp Rheumatol. 2005;23:385-8.

69. Murakami H, Nakamura T, Tsurukami H, Abe M, Barbier A, Suzuki K. Effects of tiludronate on bone mass, structure, and turnover at the epiphyseal, primary, and secondary spongiosa in the proximal tibia of growing rats after sciatic neurectomy. J Bone Miner Res. 1994;9:1355-64.

70. Weinreb M, Patael H, Preisler O, Ben-Shemen S. Short-term healing kinetics of cortical and cancellous bone osteopenia induced by unloading during the reloading period in young rats. Virchows Arch. 1997;431:449-52. 